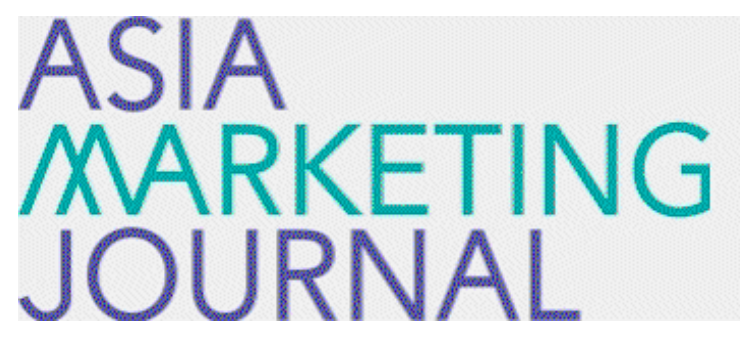

ASIA MARKETING JOURNAL

Volume 3 | Issue 2

Article 3

6-30-2001

\title{
기업의 성격에 관한 신제도학파 접근방법의 범위와 한계
}

운승여

Follow this and additional works at: https://amj.kma.re.kr/journal

Part of the Marketing Commons

\section{Recommended Citation}

여, 운승 (2001) "기업의 성격에 관한 신제도학파 접근방법의 범위와 한계," Asia Marketing Journal: Vol. 3 : Iss. 2 , Article 3.

Available at: https://doi.org/10.53728/2765-6500.1062

This Article is brought to you for free and open access by Asia Marketing Journal. It has been accepted for inclusion in Asia Marketing Journal by an authorized editor of Asia Marketing Journal. 


\title{
기업의 성격에 관한 신제도학파 접근방법의 범위와 한계* - 거래비용이론을 중심으로-
}

\section{The Scope and Limitations of the New Institutional Approach on the Nature of the Firm}

\author{
여운승(한양대학교 경영대학 경영학부 교수) \\ yeows@hanyang.ac.kr
}

\begin{abstract}
최근 20년간 마케팅을 비롯하여 사회과학 전반에 걸쳐 기업이론에 관하여 새로운 패러다임으로 각광을 받아온 신제도학파 접근방법은 이익극대화를 기업의 중심적 행동으로 가정하고 있는 신고전학파의 맹점을 극복하여 조직문제를 포괄적으로 다룰 수 있음을 보여주고 있다. 이 이론은 한정된 합리성, 기회주의, 자산 특수성, 지배구조, 신뢰 및 협동 등의 핵심적 개념들이 동태적 환경 하에서 활동하고 있는 기업의 경제적 행동을 분석하고 이해하는데 크게 기여하였음이 입증되고 있다. 이것은 다수의 실증적 문헌들에서 엿볼 수 있다.

그러나 신제도학파의 이론적 틀은 두 가지 면에서 주요 결점을 안고 있다. 그 하나는 이론의 정당성을 입증하기 위한 실증적 연구결과물을 무수하게 찾아볼 수 있으나, 대부분이 연구의 타당성이 결여되어 있다는 점이고, 또 하나의 결정적 결함은 신고전학파와 마찬가지로 비교정태적 접근방법을 택함으로써 역사적 관점이 도외시되고 기업의 전략개발과 구조적 변동을 이해하는데 필수적인 조직과 기술간의 동태적 상호작용의 중요성을 간과하고 있다는 점이다.

이에 따라 본고에서는 국제교역 이론가들이 제시한 기업 특유의 경쟁우위에 관한 착상과 그러한 우위가 기업 내외의 네트워크 형성을 포함하여 결집된 조직역량에서 도출된다는 견해를 거래비용이론에 접목시킴으로써 기업의 성격과 그 성장방식을 보다 설득력있게 이해할 수 있으리라는 관점을 제시하려 하였다. 이와 같이 거래비용이론과 진화론을 결합하면 신제도학파 기업이론의 결점이 보완되고 이론의 발전이 한 단계 진일보할 것으로 기대된다.

특히 마케팅 연구자들이 거래비용이론의 경우와 마찬가지로 본고에서 제시한 통합이론에 대해서도 실증적 연구를 행하면 이론개발에 크게 기여할 것으로 생각된다.
\end{abstract}

* 논문접수: 01.11 게재확정: 01.12

본 논문은 2001학년도 한양대학교 교내연구비에 의하여 연구되었음. 


\section{1. 머리말}

기업의 성격에 관한 신제도학파 접근방법은 지난 20년간 마케팅을 비롯하여 사회과학 전반에 걸쳐 주요 패러다임으로 부상하여 온 거래비용이론을 중심으로 실증적으로나 이론적으로 계속 발전하고 있다. 이 이론은 특히 최근에 이르러 다수의 국가에서 제도적 변화가 급속히 진행됨에 따라 기업을 제도 속에 내재되어 있는 존재로부터 점진적으로 변화 내지

진화하는 실체로 이해하는 것이 중요하다는 현실적 가정 하에서 전개되어 오고 있다. 그러한 제도적 변화란 소련을 비롯한 동구권 국가들에서의 계획경제 붕괴는 물론 자본주의 국가에서의 정부규제 완화와 공공부문의 민영화 및 새로운 위탁경영방식의 도입, 범세계적으로 빈번하게 발생하고 있는 대규모 기업인수. 합병, 활발한 경영진 인수, 전략적 제휴 및 기업간 네트워크 형성 등 다양한 기업지배장식의 탄생 등을 말한다.

이러한 신제도학파의 기업이론은 거래비용 경제학을 중심으로 재산권 경제학, 본인대리인 이론 및 진화경제학 등의 입장에서 제도, 계약, 거래비용, 한정된 합리성(bounded rationality), 기회주의, 지배구조, 신뢰, 협동 및 점진적 변화 등의 핵심적 개념들이 동태적 환경 하에서 활동하고 있는 기업의 조직과 행동을 폭넓게 설명할 수 있음을 보여주고 있다. ${ }^{1)}$ 다시 말하면 전통적인 신고전 경제학에서의 이익 극대화 가정이 기업의 행동을 적절하게 설명하지 못하고 있다는 의문이 제기되어, 기업이 상이한 목적을 지닌 이해관계집단들로 구성되어 있다는 인식이 확대됨에 따라 조직 자체를 재검토할 필요가 발생하였고, 한 걸음 더 나아가 기업을 ' 계약집합체' (nexus of contracts)로 볼 수 있다는 관점이 Coase(1937, 1993)에 의하여 제기되어 기업의 성격을 재조명하는 계기가 되었다. ${ }^{2)}$

신고전 경제학에서는 경쟁적 시장에서 자원배분과 가격수준이 모두 수요와 공급의 상호작용에 의하여 결정된다고 보지만, Coase는 대기업이 자체의 틀 내에서 자원을 조정하고 배분하려 하며, 따라서 시장의 기능을 대신한다는 사실에 주의를 기울이게 되었다. 시장이 작동되려면 비용이 소요되며, 하나의 조직을 형성하여 자원을 관리할 권한을 ' 기업가' (entrepreneur)에게 부여함으로써 어떤 시장비용은 절약된다. 기업가는 그가 대체할 수 있는 시장거래보다 낮은 가격으로 생산요소들을 획득할 수 있다는 사실을 감안하여 적은 비용으로 자신의 기능을 수행하지 않으면 안 된다. 그 이유는 그가 그러한 과업을 수행하지 못한다면 언제든지 공개시장으로 복귀될 수 있기 때문이다(Coase, 1937, p. 386). 따라서 기업은 자원이 배분될 수 있는 수단으로서 시장을 대치하는 장치로 나타나게 된다.

기업을 이러한 방식으로 이해하게 되면 그 조직적 특성에 관심이 집중된다. Coase가

\footnotetext{
1) 신제도학파 기업이론의 최근 동향을 살펴본 국내논문으로 김석용(1996) 을 참조. 거래비용이론을 중 심으로 재산권 이론, 본인-대리인 이론 및 진화경제학 등 신제도학파의 다양한 접근방법을 다룬 문헌 으로 여운승(1998)을 참조. 또한 현대기업의 성격에 관한 다양한 이론적 접근방법과 논쟁을 역사적 관점에서 비교, 평가한 논문으로 여운승(1999)을 참조.

2) 기업을 계약집합체로 볼 수 있다는 착상은 Coase $(1937, \mathrm{p} .336)$ 에서 비롯되었으며, 그에 의하면 기 업이 모든 생산요소의 중심적 계약대리인이 되어 거래의 수를 줄일 뿐만 아니라 기업에서는 해야할 임무와 이와 관련된 정확한 조건들에 대한 협상이 발생하지 않기 때문에 거래비용을 절약하게 된다.
} 
제시한 기업의 개념은 사실상 널리 알려져 있었으나 신고전 경제학의 이론적 틀에 맞추기가 적합하지 않음으로 인하여 근래에 이르기까지 본격적으로 탐구되지는 않았다. 그러나 거래비용이론에 관한 최근의 연구물들은 Coase의 논문에 직접 기초하고 있다. 이 이론에 의하면, 기업이란 단순히 생산함수가 아닌 하나의 '지배구조' (governance structure) 로 인식된다. 사실상 기업과 시장은 모두 거래비용(즉, 경제를 운영하는데 소요되는 비용)을 어느 정도로 절약할 수 있는가에 따라 선택될 수 있는 하나의 지배구조로 정의된다.

기업의 성격을 이러한 관점에서 바라보기 시작한 신제도학파 기업이론은 조직구조, 자원배분 및 균형과정간의 관계에 주안점을 두고 있다. 이 이론은 방법론상 신고전경제학의 토대가 되는 개인주의를 존속시키면서도 구(舊)제도학파 경제학의 맥락에 의존하여 기업의 경계선을 결정짓는 요인과 적절한 지배시스템이 무엇인가를 설명하고자 한다. ${ }^{3)}$ 분석의 초점은 거래 및 거래발생 범위내의 상황에 두고 있다. 주어진 상황 하에서 어떠한 제도나 조직구조가 채택될 것인가를 예측하기 위하여 정규적 교환과정, 교환을 뒷받침하고 있는 자산의 유형, 불확실성과 인간행동에서의 인지 한계, 그리고 사회의 관습과 가치관 등이 모두 통합적으로 원용된다. 일반적인 가정은 여타 비용에 비하여 거래비용의 수준이 낮을수록 자원배분이 기업보다는 시장 내에서 발생할 가능성이 크다는 것이다.

WIII iamson(1975)에 의하면 거래비용은 한정된 합리성, 기회주의 및 자산의 특수성에 기인하며, 기업이라고 하는 계층조직(hi erarchy)에 의한 시장의 내부화가 전반적 효율을 증대시킨다. 기업들은 거래 당사자들간의 계약협정 결과물이다. 시장의 비효율을 제거시키는 것이 곧 기업의 존재 이유가 된다. 계층조직(기업의 조직과 관리비용)에 소요되는 비용이 주어졌을 때, 기업의 경계선은 추가 거래의 발생이 그러한 거래가 시장이나 여타 기업에 의하여 조직될 경우와 동일한 효율을 거둘 때 결정된다. 따라서 시장과 계층조직의 혼합은 전반적 효율을 증대시킨다. 이와 더불어 거래비용으로 인한 시장의 내부화는 기업의 점진적 변화와 전략을 설명할 수 있으며, 특히 전략적 제휴, 기업간 네트워크 구축, 합작투자 및 프랜차이징(franchising) 등과 같은 새로운 형태의 혼합조직은 효율을 달성하기 위한 수단으로 탄생한 것이며, 시장에서 혼합형 조직으로, 그리고 기업이라는 계층조직으로의 진행을 암시하고 있다(WIIi amson 1993). 요컨대 효율의 추구는 기업, 혼합형 조직 및 시장의 존재 이유를 설명하는 것이다.

이와 같이 기업의 성격을 설명하는데 있어 거래비용이론을 주축으로 하는 신제도학파 이론은 다양한 형태의 기업조직패턴에 대한 새로운 관점을 제시함으로써 이론개발에 크게 기여한 점에 대해서는 의문의 여지가 없다(Densetz 1997, p. 426). 그러나 이 이론에 대하여 비판적인 견해도 다수 존재하고 있고, 실제로 여러 가지 한계점을 지니고 있는 것도 사실이다. 대표적인 예로, (1) 아직까지도 거래비용을 만족할만한 수준까지 조작적으로 정의하지 못하고 있고, (2) 기업조직의 점진적 변화과정을 적절하게 다루고 있지 못하며, (3) 기업이 조직방식을 선정할 경우에 전략의 중요성을 간과하고 있다는 점 등을 들 수 있다. ${ }^{4)}$

\footnotetext{
3) 구제도학파와 신제도학파의 차이에 대해서는 Hodgson(1989) 을 참조.

4) 신제도학파 기업이론은 이러한 결점을 지니고 있다는 비판 외에도 그것이 제도를 연구대상으로 삼 고 있음에도 불구하고 개인과 구별되는 제도의 독자적인 이론적 지위를 인정하지 않는 역설을 안고 있다. 신제도학파는 이러한 점에서 기본적으로 기존의 신고전학파 경제학에 대한 비판이라기 보다 보 완적 성격을 갖는다. 한 걸음 더 나아가 신고전학파의 가정들을 그동안 적용하지 않았던 현상들에게 까지 적용한다거나, 지금까지 정치학이나 사회학 등 다른 사회과학 고유의 분석대상이었던 사회적 제 도에까지 확장해 적용한다는 점에서 사회과학을 식민지화하고 있다는 지적도 있다.
} 
이에 따라 본고에서는 신제도학파 기업이론의 발전과정을 재조명하여 보고, 지금까지 마케팅과 여타 사회과학분야에서 연구된 실증적 문헌들에서 발견되었던 방법론상의 문제점들을 검토함으로써 기업의 성격을 설명하는데 있어 이 이론의 기여도를 비판적으로 평가하여, 진화론자들의 조직역량( organi zational capabilities) 접근방법을 접목시킴으로써 기업의 경계선이 시간의 경과에 따라 어떻게 변화할 것인가에 관하여 새로운 관점을 제시하여 이론의 발전가능성을 모색하고자 한다.

이와 더불어 마케팅 연구자들이 지금까지 거래비용이론의 핵심적 구성개념들간의 관계에 대하여만 실증분석에 초점을 두어온 관행을 탈피하여 조직역량을 포함한 통합이론의 주요개념에 대해서도 실증적 연구를 진행함으로써 이론개발에 기여할 수 있음을 제안하고자 한다.

\section{2. 신제도학파 기업이론의 기원과 발전과정}

\section{1 이론의 역사적 기원}

신제도학파의 기업이론은 Commns(1934)의 저작과 Coase(1937)의 논문이 그 효시라고 볼 수 있다. 제도주의를 옹호하였던 Commons는 거래를 분석단위로 간주하였고, 그에게 있어 제도란 ' 실행규칙의 지침 내에서 일련의 거래에 종사하는 하나의 계속기업(going concern)' 의미하는 것이었다(Dugger 1979). 모든 거래는 사회 내에서 이득을 배분하는 거래, 경영관리적 거래, 또는 재산의 교환과 관련되는 거래 등이 포함된다. 생산과 분배는 국가나 기업 내에서 법률적 해결방식 대신에 내부 지침에 의한 지배방식에 의하여 조화를 이룬다(Commons 1934).

기업을 대표적인 예로 볼 수 있는 모든 제도(또는 기관)가 거래를 비교적 효율적으로 조정하는 수단으로 본다면, 그 기원과 범위를 어떻게 보아야 할 것인가? Commons는 사업가나 노동자와 같은 보통의 사람들에 의한 집단적 행동이 특정된 목적을 달성하기 위하여 하나의 제도를 창출하는 점진적 변화과정을 지지하였다(Seckl er 1975). 반면에 신고전 경제학의 영향을 받은 Coase(1937, p. 390)의 경우, 기업의 기원은 집단적 내지 의도적 행동이 아니라 사업을 영위하는데 소요되는 거래비용에 대한 개인들의 반응에서 찾을 수 있으며, '기업을 설립하는 것이 이익이 되는 주된 이유는 가격 메카니즘을 이용하는데 비용이 소요되기 때문인 것으로 보인다.' 물론 여러 과업을 내부화 한다 하더라도 상품과 서비스는 여전히 어느 정도 매매되어야 하기 때문에 시장에서의 거래비용을 완전히 제거할 수 없지만, 생산자가 투입물과 산출물에 대하여 다루게 될 계약의 수는 훨씬 줄어들 것이다. 그러나 경영관리 내지 생산의 조정에 비용이 소요되지 않는 것은 아니며, 이에 따라 Coase는 1930년 당시의 신고전 경제학의 정설을 반영하여 관리적 측면에서 본 규모의 불경제 개념과 일치하는 방향으로 자신의 주장을 옹호하려 하였다. 따라서 그는 생산자가 경영관리비용이 시장에서 거래하는 비용과 같아질 때까지 모든 활동을 계속 내부화할 것이라는 단순한 한계법칙에 따라 기업의 경계선이 결정된다고 보았다. 
초기의 이러한 착상은 보편적 문화와 기업 특유의 문화가 통합된 실행규칙의 개발과 지배구조의 점진적 변화가 기업과 시장이 어떻게 성장할 것인가를 설명할 수 있는 보다 현실적인 기업이론의 토대가 되었다. 특히 1950년대까지 신고전 경제학에서는 기업의 이익 극대화 가정에 집착하여 기업행동을 적절하게 설명하지 못하게 됨에 따라, 이에 불만을 느낀 다수의 행동과학자들이 새로운 시각으로 조직행동을 탐구하기 시작하였다. 이들을 주도하였던 March와 Si mon( 1958) 도 기업을 집단적 조직의 개념으로 소개하였고, 상충되는 목적들이 해결되어 목표로 변환되는 과정에 주의를 기울였다. 이들이 기업이론의 발전에 크게 기여한 점은 시스템, 구조 및 규칙을 도입하여 기업이 목표를 달성하고 변화하고 있는 환경에 적응하는데 필요한 대량의 정보를 흡수하고 이에 따라 행동할 수 있게 됨에 따라 개인의 인지 한계를 극복하려는 노력이 어떻게 이루어지는가를 탐구하였다는 것이다. 특히 정보를 입수하고 처리하는데 소요되는 비용이 타협적 희생(satisficing)과 경험에서 터득한 전략의 추구를 의미한다는 착상은 당시까지도 신고전 경제학자들에게 수용되지 못하였다.

그러나 이들이 경영자본주의의 결점에 대하여 주의를 기울이게 됨에 따라 기업의 성격에 관한 전통적인 견해는 점차 지지하기가 어렵게 되었다. 그러한 경향을 주도한 학자는 Baumbl (1959)로서, 그는 기업의 소유와 경영이 분리됨에 따라 경영층에서는 최소한의 이윤을 달성하는 전제 하에 자신의 목표인 판매극대화를 추구하기 위하여 불균형적(또는 비대칭적) 정보(assymmetric information) 를 이용할 것이라고 주장하였다. 불균형적 정보의 이용이라는 착상은 Marris(1964)도 지지하여, 기업이 인수되는 위험을 감수하고라도 장기적인 성장을 뒷받침하기 위하여 경영자들은 이윤을 전용할 수 있다고 믿었다. 그러나 두 사람 모두가 신고전 경제학의 뿌리를 벗어나지 못하여 대기업의 형성과 관리방식에 관하여 더 이상의 심층적 분석을 행하지 않았고, 지배구조가 성장을 뒷받침할 수 있는가의 여부에 대해서도 의문을 제기하지 않았다. 대부분의 경영이론가들은 방만한 경영자들이 적대적 기업인수를 통하여 퇴출될 수 있기 때문에 자본시장의 규율이 효과적으로 작동될 것으로 생각하였다( Nanne 1965).

자본시장이 범위가 한정된 불투명한 수단에 불과하다고 간주할 사람은 거의 없겠지만 기업의 주인(또는 본인)(principal)이 그의 대리인(agent)들을 어떻게 효과적으로 통제하는가에 관한 의문이 여전히 남게 된다. 통제에는 두 가지 측면이 내포되어 있다. 즉, 주인의 입장에서는 대리인이 자신의 목적을 위하여 자원을 이용하는 것을 금지시켜야 할 뿐만 아니라 자원을 효율적으로 이용할 확실한 보장을 필요로 한다는 것이다. Al chi an과 Densetz(1972)는 이 문제를 중요시하여 거래비용의 극소화보다는 책임회피(shirking) 행위가 기업의 존립근거가 된다고 주장하였다. 이들에 의하면 팀(즉, 기업)에 의한 생산에서 획득되는 이익을 확보하기 위하여 팀 구성원들 가운데 감독자를 임명하여 투입물에 대한 계약을 협상하고 책임을 회피하는 구성원들을 통제할 권한을 부여하는 것이 효과적이다. 감독자는 그 보상으로 투입물 공급자에 대한 대가를 지불한 후의 잔여이윤을 차지하며 사실상의 기업 소유자가 된다.

기업이 계약결합체에 불과하다는 명제는 소유자가 경영하는 기업에 관하여 역사와는 무관한 흥미로운 관점을 제시하였다. 이것은 또한 공식적이거나 비공식적인 모든 규정에 근거한 집단적 행동을 통하여 개별 거래활동이 조화를 이루는 하나의 제도(또는 기관) 가 곧 계속기업으로 볼 수 있다는 Commons의 주장과 일맥상통하고 있다. 그러나 Alchi an과 Densetz(1972) 는 소유자가 경영하는 기업이 성장하기 위하여 효율적 계약을 뒷받침할 규정, 가치 및 일상적 과업과 필요한 통제 시스템에 관하여만 간략하게 논평하였을 뿐이고 기업의 
존재와 조직의 근거가 되는 불완전한 지식과 예측할 수 없는 환경적 요인들과 같은 개념을 거부하였다(Alchi an and Demsetz 1972, p. 784-5). 신제도학파 기업이론에서는 이들의 논거를 탈피하여 기업의 성장이 바로 시장실패를 극복하기 위한 것이며, 특히 불확실성 하에서 시장에서의 거래비용과 거래상의 난관을 줄이는데 그 의의가 있다고 주장하기 시작하였다.

\section{2 이론의 발전적 전개}

신제도학파 기업이론의 체계는 WIIi amson(1975, 1985)에 의하여 본격적으로 완성되기 시작하였다. 그는 Commons의 견해를 따라 경제활동이 하나의 실행규칙 틀 내에서 발생하는 일련의 거래로 간주하였고, Coase의 논거에 따라 시장에서의 계약체결과 시행에 소요되는 비용이 상대적으로 높을 때 거래의 소재가 시장에서 기업으로 이동한다고 보았다. 그러나 여기에서 제기되는 중요한 문제는 시장거래에서 발생하는 정보탐색, 협상 및 계약시행에 소요되는 비용 등을 구분, 파악하는 것이다.

WIII amson은 March와 Si mon(1958) 등 행동과학자들의 연구결과를 토대로 거래비용의 발생이 한정된 합리성과 기회주의라는 두 가지 행동특성에 기인하며 소수의 교섭과 불확실성과 관련된 복잡성의 두 가지 환경적 특성이 결부된다고 보았다. 한정된 합리성은 ' 실제 세계에서 합리적 행동을 객관적으로 해결하는데 필요한 문제들의 크기에 비하여 복잡한 문제들을 공식화하고 해결할 수 있는 인간의 사고능력이 제한되어 있기 때문' 에 야기된다. 기회주의는 불균형적 정보로 인하여 조장되며 ' 교활하게 사리사욕을 추구하는 것' 을 포함하여 거래에서 순수함과 정직성이 결여되어 있음을 말한다(WIII amson 1985, p. 30) .

경쟁시장에서 다수의 반복거래가 이루어지면 경쟁과정 자체가 기회주의적 행동에 불리한 요인으로 작용함에 따라 기회주의는 위험을 거의 유발하지 않는다. 그러나 반복적 계약체결과 시행이 다변적 거래를 쌍무적 거래로 전환시켜 반영구적 관계로 정착되면, 어느 일방이 타방을 희생으로 이득을 추구할 경우에 문제가 될 수 있다. 만일 합리성이 한정되어 있지 않다면 기회주의적 행동을 포함하여 모든 상황적 요인들은 계약조건들을 문서화함으로써 적절하게 다룰 수 있을 것이다. 기회주의적 행동이 존재하지 않을 경우에 복잡성과 불확실성으로 인하여 발생하는 문제들은 발생할 때마다 계약을 재체결함으로써 적절하게 다룰 수 있을 것이다. 한 기업 내에서 기회주의를 배제하고 이익 극대화를 공동으로 추구하기 위한 거래 당사자들의 결집을 시도하려면 한정된 합리성과 기회주의를 연계시키는 일이 필요하다. 
그러나 행동과학자들이나 경영이론가들이 명백하게 제시하고 있는 바와 같이, 한정된 합리성과 기회주의적 행동의 문제는 내부화로 완벽하게 해결되는 것은 아니다. WII i anson은 Chandl er (1962) 의 실증적 연구를 토대로 분권화와 여타 통제장치의 개발을 통하여 기업 내부에서의 시장실패를 완화할 수 있다고 주장하였다. 한 걸음 더 나아가 하위부문 경영층에 의한 자체 목표 추구는 지배구조에 적절하게 조절됨으로서 제약될 수 있다. 다각화된 대규모 기업들은 대부분 각 사업부문을 독립채산제의 이익중심점으로 하여 감독 메카니즘과 본사에서 자원을 배분할 척도로 이용함으로써 하나의 소규모 자본시장의 기능을 수행한다. 본사는 특정부문의 세부적 운영실태를 상세하게 파악함으로써 외부 자본시장에 비하여 정보를 신속하게 내부에 전파하여 일상적이거나 전략적 투자결정을 용이하게 내릴 수 있다(WIIi amson 1975, p.162). 본사가 각 사업부문에 자원을 효율적으로 배분하지 못하면 자본시장에서 경영책임의 문제가 제기되어 기업인수의 결과를 초래하게 될 것이다.

경제활동의 위치가 기업과 시장에서 발생하는 거래비용을 비교함으로써 결정된다는 가설은 체계적으로 검증되지는 않았지만 WIII anson(1975)에 의하여 제기된 이론적 명제는 경제사에서 도출된 사례를 통하여 지지되었다. 즉, 그는 Adam Sminh가 언급한 핀 제조공장이 수공업에 비하여 우월한 점은 거래비용에 기인한다는 실증적 연구결과를 제시한 바 있다(WIIianson 1980). 그러나 기업과 시장에서 발생하는 비용을 비교할 방법론이 개발되지 않았고 역사적 자료를 해석하는데 있어서도 의문이 제기되어 WIIiamson의 주장은 정당화되기 어려웠다(Jones 1982). 더욱 문제가 되는 점은 거래비용 가설이 수공업제나 공장제도 중 어느 것이 더 선호되리라는 것을 사전에 보일 수 있는 요소들이 결여되어 있기 때문에 여전히 하나의 반복적 수사에 불과하다는 것을 보여주었다는 것이다.

WII i anson(1981) 은 자신의 모델에 자산 특수성(asset specificity) 이라는 예측능력을 추가하였다. 여기에서 자산 특수성이란 특정된 투자가 다른 목적으로 이용될 수 있는 정도를 말하며, 다른 용도로 이용될 수 없을 경우 계약당사자들간에 기회주의적 행동을 유발할 가능성을 높인다. 자산 특수성은 애초에 실물자산에 국한하여 언급되었으나 그 개념이 확장되어 부지, 공장, 브랜드 및 인적자본에 대한 투자까지 포함되었다(WIIi anson 1988). 그러한 투자에 대한 계약은 구매자나 판매자 측의 '사후적' (ex post) 인 기회주의적 활동, 특히 계약조건을 재협상하지 않는 한, 거래를 거부하는 것이 '사전적' (ex ante) 투자를 저해할 가능성이 있다 하더라도 '사전에' 체결될 수 있다. 따라서 '자산 특수성이 높을수록 구매자와 판매자는 지속적인 교환관계를 유지하려는 특별한 노력을 기울일 것이다.' (WIIi anson 1981, p.1546). 그는 자산 특수성의 정도를 파악하면 시장, 기업 및 그 중간의 지배구조(예컨대 합작투자)의 세 가지 중에서 어느 형태를 선호하게 될 것인가를 예측할 수 있다고 하였다. 일반적으로 비(非) 특수투자는 시장지배의 결과를 낳는 반면, 특수투자와 반복거래는 기업(혹은 단일) 구조의 결과를 낳을 것이다. 거래가 빈번하지 않고 자산 특수성의 정도가 혼재되어 있거나 높을 경우에는 (예컨대 설비의 구매가 관례화되어 있거나 공장을 건설하는 경우) 3자간 지배(trilateral governance)가 최적이며, 계약당사자간의 분쟁은 중재에 부쳐진다 $<$ 그림 1> 참조). 


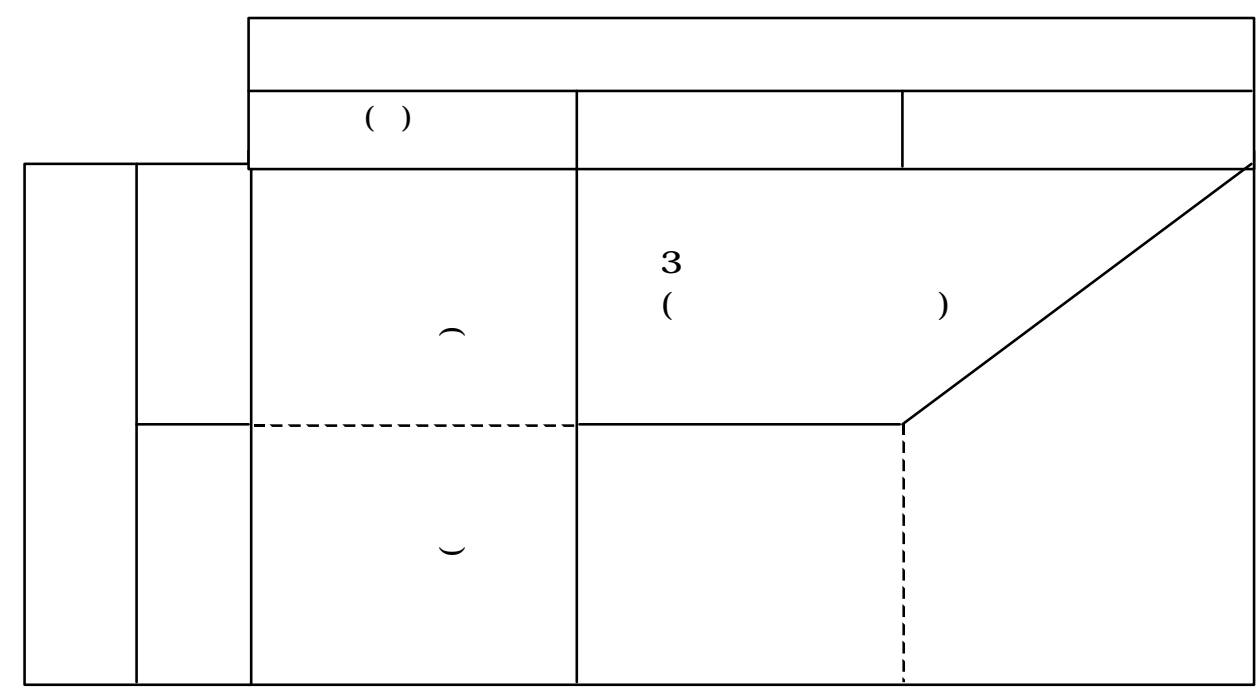

자료 : WII i amson, O. E. ( 1985) The Econom c I nst i t ut i on of Capi tal i sm, New York: The Free Press, p. 79.

지금까지의 논의를 통하여 알 수 있는 것은 자산 특수성이 없으면 한정된 합리성과 기회주의는 전혀 문제가 되지 않는다는 점이다. 그 이유는 비교적 비용을 들이지 않고도 재계약을 체결할 수 있기 때문이다. 이것은 대부분의 교환유형에서 기업이 시장을 대신할 이유가 없는 것으로 생각되기 때문에 중대한 의미를 지니고 있다. 그러므로 자산 특수성의 개념은 일반화하기 어렵지만 신기업이론의 예측능력을 제고하는데 크게 기여하였는 바, 그 이유는 이 이론이 기업의 존재 이유보다 대규모의 자본집약적 기업이 수직적 통합이 이루어지는 이유에 초점을 두게 되었기 때문이다.

\section{3 자산 특수성 접근방법의 한계}

구(舊) 제도경제학에서는 새로운 제도적 형태를 설명하기 위하여 환경과 가치관의 변화에 대한 실행규칙의 적응방식과 같은 변화의 과정에 관심을 둔다. WIIiamson이 주도한 신제도학파 기업이론은 ' 제도' (institutions)라는 명칭을 채택하고는 있으나 그 기본적인 착상은 Commons의 점진적 변화(또는 진화론적) 접근방법보다는 Coase의 선택이론법에 의존하고 있음이 분명하다. 즉, 조직양식(그것이 시장이나 기업 또는 그 중간의 거래형태 등 무엇이든 간에) 은 기본적으로 가능한 모든 양식과 그에 따르는 비용을 사전에 확인할 수 있다는 비교정태적 접근방법을 원용하고 있다. 이러한 면에서 신제도학파 이론은 조직양식의 선택이 하나의 수리적 최적화 과제의 일부로 통합될 수 있는 신고전학파 이론의 연장에 불과하다(WIII anson 1981, p. 1546).

최적화가 이루어지려면 거래비용을 사전에 확인하여 측정하는 일이 필요불가결하지만, 이는 간단한 일이 아니다. 일반적으로 거래비용은 정보탐색과 협상에 소요되는 ' 사전적' 비용과 계약시행에 따르는 '사후적' 비용으로 분류되고 있다. 시장을 이용하는데 
소요되는 비용은 '사후적' 비용을 개략적으로만 추정할 수 있다 하더라도 비교적 쉽사리 파악할 수 있다. 기업지배에 소요되는 비용을 추정하는 일은 횔씬 어렵다. 그 이유는 내부시장을 이용하는데 소요되는 비용을 파악, 분류하여 타당한 비교가 가능하도록 평가할 수 있어야 하기 때문이다.

내부시장을 이용하는데 소요되는 비용(이것은 문헌에서 흔히 지배, 관리 및 조정비용이라고 불리운다)을 판정할 경우에 당면하게 되는 주요 문제는 인적 및 물적 자원이 기술적으로 분리가능한 단계(준(準)시장기능)와 생산간의 흐름을 조정하는데 흔히 이용되고 있다는 점이다. 다종제품을 생산하는 기업에서 기능을 전문화하고 사업부제를 택하면 비용을 구분하여 파악하는데 도움이 될 수 있으나, 간접비를 배분하는 문제와 고객들의 욕구를 충족시키기 위하여 제품의 흐름과 특성을 바꾸는 것과 같은 적응활동이 관리나 생산업무 중 어디에 속하는가와 같은 문제들은 여전히 잔존한다. 어떠한 경우이든간에 내부화는 거래비용을 완전히 제거하지 못한다. 기업은 여전히 투입물을 구입하고 산출물을 팔아야 하기 때문이다. 구매된 투입물에는 공급기업 자체의 관리비와 생산비가 내포되어 있어 이에 대한 비교평가는 의사결정과정에 반영되어야 한다(Densetz 1988). 따라서 거래비용이 0일 경우에도 기업의 내부 관리비와 생산비가 공급자에 비하여 적다면 후방통합이 더 유리할 수 있을 것이다. 이와 마찬가지로 관리비와 생산비가 유통부문과 같은 하류(下流) (downstream) 기업에 비하여 적다면 전방통합을 시도할 것이다.

그러므로 거래비용, 관리비 및 생산비 등은 제품의 생산, 구매 또는 판매 여부에 따라 영향을 받으며, 조직양식의 선택(기업, 시장 및 그 중간형태의 3자 중 선택)은 그러한 비용들간의 균형정도에 달려 있다. 경우에 따라 원료나 부품을 직접 생산할 것인가 또는 구매할 것인가의 여부는 극히 간단하게 결정될 수 있으나, 적절한 비용을 확인하여 측정하기가 어려울 경우가 많다. 실제로 한정된 합리성과 관련하여 복잡성과 불확실성이 존재할 경우, 의사결정자는 어떤 조직양식을 택할 것인가에 관하여 충분한 정보를 보유하지 못함으로써 의사결정을 내릴 수 없게 된다고 주장되어 왔다(Hodgson 1993). 의사결정자는 어떠한 경우이든 미래의 비용, 수요의 변동, 가동율, 신기술에 관한 전망, 생산요소의 구입가능 여부 및 비교정태적 모델에서 배제된 여타 요소 등에 관한 기대 등을 자신의 의사결정에 통합하고자 한다. 그러므로 내부화 여부에 관한 의사결정은 정확한 계산의 문제가 아니라 판단 및 경험과 함수관계에 있으며, 여기에는 비교가능한 비용의 추정과 위험의 정도가 포함될 것이다. 이러한 환경 하에서 실행에 필요한 것은 시간의 경과에 따라 점진적으로 형성된 의사결정 규칙과 불확실성의 조건 하에서 위험을 감수할 태세를 갖추고 기회만 있다면 혁신적 해법을 창안할 수 있는 기업가 정신이다. 그러나 WIII amson이 명시한 비교정태적 세계에서는 이러한 기업가 정신이 배제되어 있다.

WIIianson의 초기 모델은 다소 기술적(記述的)이었으나 그가 자산 특수성의 개념을 도입하여 보다 적합하고 예측력이 있는 모델을 개발함에 따라 비용을 확인하여 계산하는 문제는 어느 정도 제거되었다. 앞에서 알 수 있었던 바와 같이 자산 특수성의 정도가 높지 않으면 수직적 통합의 여지는 존재하지 않는다. 기회주의적인 자산 소유자는 자신의 자원을 다른 용도로 쉽사리 이전시킬 수 있기 때문이다. 달리 말하면, ' 자산 특수성이 클 경우에 구매자와 판매자는 지속적인 교환관계를 유지하고자 할 것이다' (WIII amson 1981, p. 1546).

그러나 자산 특수성의 정도는 어떻게 측정할 수 있는가? 특히 인적자산의 경우, 수직적 통합이 이루어지기까지 어느 정도의 잠재적 손실이 발생하여야 하며, 자산 특수성의 정도와 발생된 손실과는 어떠한 관계가 있는가? 유능한 회계사가 장부대체가격으로 실물자산의 
잔존가치를 계산할 수 있겠지만, 그러한 자산을 차후에 최대로 이용할 경우에 발생할 가상의 소득 흐름과 이용하지 않음으로써 포기된 소득 흐름과의 차이를 추정하는 것은 간단하다고 볼 수 없다. 무형의 자산을 이전시킬 경우의 손실을 평가하기란 더욱 어려울 것이다. 어떠한 경우이든 자산의 이전은 최후의 수단임을 나타내며, 그렇게 함으로써 초래될 손실은 절대적 한계를 설정하게 될 것이다. 만일 경영층에서 부당한 위협(hol dup) 이 불규칙적으로 발생하거나 단기적일 것으로 믿는다면, 이로 인한 손실은 적고 감내할 수 있는 정도이기 때문에 통합의 필요성은 소멸될 것이다. 실제로 자산 특수성의 정도가 크지만 수직적 통합이 규범화되지 않는 산업을 흔히 찾아볼 수 있다. ${ }^{5)}$ WIIi anson은 일본의 기업들이 미국에 비하여 원료나 부품을 직접 생산하기보다는 외부에서 구입하는 경향이 많으나 그것이 의도적이든 또는 그렇지 않든간에 부당한 위협 문제를 상당히 감소시킬 수 있는 기업간 네트워크 시스템이나 문화적 가치관 또는 기업의 관행에 대해서 이야기하는 바가 거의 없음을 인정하고 있다(Casson 1990).

\section{3. 거래비용이론에 관한 실증적 연구의 성과}

Coase와 WIII amson이 주도하여 발전되어 온 거래비용 중심의 신제도학파 기업이론의 타당성을 입증하기 위한 실증적 연구가 사회과학 전반에 걸쳐 활발하게 진행되어 왔다. 그러한 다수의 연구가 이론의 구성개념(construct)을 조작적으로 정의하여 이론을 검증하는데 어느 정도로 기여하였는가에 대해서는 논자에 따라 견해가 다르지만, 이들의 포괄적 평가를 요약하면 다음과 같다. ${ }^{6)}$

\section{1 연구영역}

거래비용이론에 관한 실증적 분석은 법학, 경제학 및 마케팅을 비롯한 경영학의 학제간 구성개념의 통합을 토대로 경제조직의 다양한 문제들을 설명하는데 초점을 두어 왔으나, 그 연구영역은 대체로 수직적 통합, 조직간 수직적 관계, 조직간 수평적 관계 및 거래비용이론에서의 제(諸) 가정 검정 등으로 분류할 수 있다.

거래비용이론에 관한 초기의 실증적 연구는 대부분 수직적 통합에 관한 의사결정에 초점을 두었다. 그러한 연구들은 주로 원료 및 부품 공급업체에 대한 제조기업의 후방통합과 유통업이나 판매활동에 대한 전방통합에 관한 의사결정이 주류를 이루었다. Nonteverde와 Teece(1982a) 는 미국의 두 자동차 회사에 대한 조립부품의 자체생산 또는 외부로부터의 구매여부에 관한 의사결정을 조사하기 위하여 거래비용이론을 적용함으로써 후방통합의 논거를 제시하여 이론의 타당성을 입증하였다는 평가를 받기도 하였다. 그 이후

\footnotetext{
${ }^{5)} \operatorname{Demsetz}(1988$, p.174) 는 자신의 실증적 연구가 치밀하지 못하다는 점을 인정하면서도 수직적 통합 과 자산 특수성간에는 거의 상관관계가 없음을 밝힌 바 있다.

6) 신제도학파에서 중심적 위치를 차지하고 있는 거래비용이론에 대한 실증적 연구성과를 포괄적으로 평가한 최근 문헌으로는 Anderson (1996), Lothia, Brooks, and Krapel (1994), Pessali and Fernandez (1999), Rindfleisch and Heide (1997), Schelanski and Klein (1995), Williams (2000) 등 을 들 수 있다. 이하에서는 이들의 평가를 요약하여 설명하였다.
} 
거래비용에 입각한 후방통합의 실증적 논거는 무수하게 제시되었다. 전방통합의 논거에 관한 연구도 활발하게 진행되어 John과 Weitz(1988)의 연구를 효시로 다수의 문헌을 찾아볼 수 있고, 최근의 문헌으로 $\mathrm{Kraft}$ (1999)의 연구를 들 수 있다.

전방통합과 관련하여 해외시장의 진출방식에 관한 분석도 많이 찾아볼 수 있다. 예컨대 Ander son과 Coughl an(1987) 은 미국의 반도체 기업들이 해외시장에 진출하는데 독립된 유통경로와 통합조직의 이용을 조사하기 위하여 거래비용이론을 원용한 바 있고, Kl ei n과 $\operatorname{Roth}(1993)$ 는 기업이 국제마케팅경로에 대한 만족도를 충족시키는 요인들을 이해하는데 거래비용이론을 이용함으로써 이 분야에 관한 연구개발에 크게 기여하였다. 해외시장 진출방식에 대한 거래비용이론의 실증적 연구문헌은 그 외에도 다수가 있지만, 최근의 논문으로 첨단기술산업에서의 신진기업들이 국제시장 진출방식을 어떻게 선택하는가를 조사한 Burgel 과 Murray(2000)의 글과 합작투자를 자원기반이론과 거래비용이론을 토대로 분석한 Tsang( 2000) 의 것을 들 수 있다.

거래비용과 관련하여 수직적 통합과 밀접한 관련이 있는 분야로 공동의 소유(즉 완전통합)형태를 갖지 않고 지배문제를 어떻게 관리할 수 있는가에 초점을 두는 조직간 수직적 관계에 대한 다양한 연구들이 있다. ' 혼합형' (hybrid form) 지배 메카니즘에 관한 최초의 연구자인 Monteverde와 Teece( 1982b)는 미국 자동차 산업에서의 준(準)수직적 통합 (예컨대 공급자가 부품을 생산하지만 제조업자가 생산시설을 소유하는 경우) 의 선행조건들을 조사한 바 있다. 그 이후 지금까지 거래비용이론에 관한 실증적 분석에서 가장 많이 연구된 것은 혼합형 지배구조로서 주로 조직간의 지속적 유대관계 발전에 관하여 초점을 두고 있다. Hei de와 John( 1990) 은 거래비용이론을 토대로 구매자들과 공급자들이 특수 투자를 보호하고 불확실성에 적응하기 위한 수단으로 상호간에 밀접한 관계를 어떻게 유지하는가를 연구한 바 있고, St ump와 Hei de( 1996)는 화학산업에서 제조업자와 원료공급자간에 파트너 선정방식, 인센티브 설계 및 감독활동 등을 포함한 다양한 형태의 지배 메카니즘을 조사하였다. 지배구조에 관한 이러한 부류의 연구물들은 흔히 찾아볼 수 있다. 특히 장기적인 쌍무적 교환관계를 조사함으로써 조직간 수직적 관계에 관한 연구개발에 크게 기여한 Joskow (1987) 는 석탄공급자와 전력회사간의 장기계약을 결정하는데 자산 특수성의 역할을 탐구하였고, 그 이후에도 이와 유사한 연구들이 진행되어 왔다.

다른 한편 거래비용이론에 관한 실증적 분석에서는 대부분 수직적 관계에 초점을 두고 있으나 가치사슬에서 동일선상에 있는 기업들간의 다양한 관계를 설명하기 위한 연구도 점증하고 있다. Gates(1987)는 반도체 산업에서의 기술협력에 관한 자신의 분석에서 조직간 수평관계에 대하여 거래비용이론을 처음으로 적용하였다. 좀더 구체적으로 말하면, 그는 한 기업의 전략지향성이 기업간 협동과 관련되는 거래비용에 대한 경영자의 인식을 바꾸는 정도를 검토하였다. 그 이후 Buckl in과 Segupta(1993) 는 공동마케팅 제휴에서 자산 특수성, 불확실성 및 권력 불균형상의 빈도의 역할에 관하여 탐구함으로써 조직간 수평적 관계에 대한 연구가 널리 알려지게 되었다. 그 외에 이 분야에 관한 실증적 연구로서 Osborn과 Baughn( 1990), Parkhe(1993) 및 White( 2000) 등을 들 수 있다.

실증분석의 나머지 영역은 거래비용이론의 제(諸) 가정을 검정하는 것으로 가정의 타당성을 조사한 문헌을 찾아볼 수 있다. John(1984)은 주요 석유회사의 프랜차이즈 가맹점들이 권력과 관료주의적 구조의 결과로 보여준 기회주의적 행동의 정도를 설명하고 조사하기 위하여 기회주의를 외생변수로 간주하였고, Ander Son(1988) 도 전자부품산업에서 판매원들간의 기회주의적 행동에 대한 선행조건들을 연구하였다. Noschandr eas(1997)는 
기회주의의 역할을 비판적으로 검토하고 기업의 계층적 구조가 행동에 역효과를 초래하며 기회주의의 활용에 일관성이 없음을 지적한 바 있다. 그밖에도 Bensaou와 Ander son(1997) 은 자산 특수성과 같은 변수의 선행조건들을 탐구하기 시작하였다.

\section{2 측정변수}

거래비용이론에 관한 실증적 연구영역은 위에서 언급한 바와 같이 다양하며, 자료수집과 측정방법도 매우 다양한 면을 보이고 있다. 마케팅을 비롯한 여타 사회과학에서는 자료를 수집할 경우, 2 차자료와 표본조사 및 실험설계와 같은 1차자료를 이용하는 등 조사의 필요에 따라 선별적으로 이용하고 있음을 발견할 수 있다. 그러나 실증분석에서 보다 중요한 문제는 구성개념을 조작적으로 정의하는 일이다. 거래비용이론에 대한 실증적 분석에서 이 문제가 중요한 이유는 다수의 연구물들이 측정상의 난관에 봉착하여 미래의 조사에도 심대한 영향을 미칠 수 있기 때문이다. 거래비용이론에 관한 대부분의 실증분석을 보면 지배구조를 종속변수로 보고 자산 특수성, 환경적 불확실성 및 행동적 불확실성을 독립변수로 측정하고 있다.

지배구조는 이론상 시장, 계층조직(즉, 기업) 및 여러 가지 유형의 혼합 메카니즘의 3자로 분류되어, 실증연구에서도 이러한 방식을 따라 조작적으로 정의하고 있다. 그러나 일반적으로 시장과 계층조직 양자를 측정하려는 경우가 많다. 예컨대 부품을 외부에서 구입할 것인가 또는 자체 생산할 것인가를 비교하는 것이 이에 해당된다. 또는 판매부를 직접 설치할 것인가 또는 독립적인 대리점을 둘 것인가의 문제에 대한 분석도 이에 해당된다고 볼 수 있다. 그러나 지배구조를 수직적 통합의 정도로 보고 $0 \%$ 에서 $100 \%$ 까지 연속척도로 측정하는 경우도 많이 찾아볼 수 있다. 문제는 이러한 측정방법이 산업마다 수익성에 차이가 있기 때문에 왜곡될 가능성이 있다는 점이다.

한편 혼합형 지배방식에는 여러 가지가 있을 것으로 생각된다. 예컨대 해외시장에 진출하기 위하여 현지 기업과 합작투자를 하는 경우, 현지법인을 설치할 것인가(계층조직) 또는 현지 유통업자를 이용할 것인가(시장)의 문제가 이에 속한다. 또다른 혼합형 지배구조로서 구매자와 판매자간의 관계에서 공동의 노력과 지속성의 정도를 평가하는 쌍무적 지배를 측정하는 경우도 있다. 최근에는 지배 메카니즘의 범위를 확대하여 분석하고 있다. 예컨대 St ump와 Hei de(1996)는 구매자가 판매자 선정, 인센티브 설계 및 감독(monitoring)과 같은 통제 메카니즘을 통하여 판매자에 투자한 특수자산을 어떻게 보호하는가를 조사한 바 있고, Parkhe(1993)는 전략적 제휴에서 기회주의적 행동이 계약의 보호수준에 미치는 영향을 분석하였다. 특수 투자에 대한 보호에 초점을 둔 연구는 그밖에도 Dutta와 John(1995)을 비롯하여 활발하게 탐구되고 있다.

거래비용에 관한 실증분석에서 대표적인 독립변수로 측정되는 구성개념은 자산 특수성이다. 이 개념에 대한 정의는 앞에서 이미 언급한 바 있다. 자산 특수성 가운데 실증분석에서 흔히 이용되는 측정변수는 인적 자산으로서, 연구자들이 이를 선호하는 이유에는 두 가지가 있다. 첫째, 다수의 실증분석에서 인적 투자가 거래하는데 있어(판매 및 구매 등) 상당한 비용을 차지할 경우를 다루고 있기 때문이다. 둘째, 인적 특수자산은 판매보고서와 같은 2 차자료를 직접 이용하거나 표본조사와 같은 1차자료를 수집하는 등 다양한 측정방법을 동원할 수 있기 때문이다. 특히 다항목 측정척도를 이용할 경우에 내적 일관성은 물론 수렴타당성과 판별타당성이 높은 연구물들을 찾아볼 수 있고, 단일항목으로 
측정할 경우에도 내적 일관성이 있는 문헌들이 흔히 발견된다. ${ }^{7)}$ 그러나 아직까지 구성개념 타당성을 입증하는 수준에는 이르지 못하고 있다.

또 하나의 독립변수로 측정하기 위한 구성개념은 환경적 불확실성으로서, 이것은 교환과 관련하여 예상할 수 없는 환경상의 변화를 말한다. 이 구성개념은 거래비용이론에서 측정하는데 가장 문제가 되고 있다. 이를 조작적으로 정의하는데는 상반되는 두 가지 견해가 있다. 대부분의 공통적 견해는 환경적 불확실성이 예측불가능한 성격을 지니고 있다는 것이고, 또 하나의 견해는 예측불가능성과 복잡성을 모두 검토하는 것이다. Ri ndf I ei sch와 Hei de(1997) 는 이러한 두 가지 견해에 따라 예측불가능성에 초점을 두고 환경적 불확실성을 조작적으로 정의하거나 예측불가능성과 변화가능성을 측정한 다수의 문헌을 열거, 평가하고 있다. 그렇다면 어느 견해가 실증분석에서 보다 적절한 개념적 영역을 제공하고 있는가? 이에 대한 궁극적 해답은 이론적 근거에 달려 있다. 만일 조사자가 외부환경의 핵심적 요소들이 계층조직의 지배양식을 저해하는 요인으로 작용할 것으로 기대할 이유를 갖고 있다면 예측불가능성과 복잡성을 환경적 불확실성의 측정변수로 이용하는 것이 타당하며, 그렇지 않을 경우에는 전통적인 예측불가능성을 측정변수로 활용할 수 있을 것이다.

독립변수로 측정하기 위한 마지막 구성개념은 행동적 불확실성으로 이것은 교환당사자들의 계약에 의한 성과를 감독하는데 따르는 어려움을 지칭한다(WIIi anson 1985). 행동적 불확실성은 자산 특수성이나 환경적 불확실성에 비하여 실증적으로 측정한 문헌이 훨씬 적으며, 대부분 거래 당사자의 업적평가에 따르는 난이도를 측정하고 있다.

\section{3 실증적 분석의 타당성}

지금까지 살펴본 바와 같이 지배문제와 그 선행조건 및 이를 관리하는 지배 메카니즘에 관한 다수의 실증적 연구결과는 무엇을 이야기하고 있는가? 이하에서는 그러한 연구결과의 타당성을 특수자산의 보호, 적응문제 및 성과에 대한 평가문제 등으로 나누어 살펴보기로 한다.

첫째, 어느 기업이 특수자산을 보유하고 있을 때, 거래 당사자가 기회주의적으로 이용하리라고 의구심을 가질 경우에 이를 보호하는 문제가 발생한다. 따라서 특수자산을 보호하는 문제의 선행조건은 기회주의와 자산 특수성이다. 대부분의 실증적 연구물을 보면, 가장 흔히 조사한 것이 지배문제이다. 이러한 연구물들은 특수자산의 효과에 대한 가설을 상당한 정도로 지지하고 있고, 기회주의적 행동에 관한 가정에 대해서는 엇갈린 지지를 보이고 있다.

기회주의적 역할을 지지하는 대표적인 연구문헌은 Dutta와 John(1995)을 들 수 있다. 이들에 의하면 시장에서 독점적 위치에 있는 공급자가 시장을 공유하고 있는 공급자에 비하여 가격을 인상할 가능성이 높다는 것을 보여줌으로써 협상 횟수가 적을수록 기회주의적 행동을 보일 것이라는 WIII anson(1985) 의 명제를 지지하고 있다. 그러나 이와 상반되는 연구결과도 찾아볼 수 있다. 예컨대 Parkhe(1993)는 전략적 제휴에 관한 연구를 통하여 거래 당사자들간의 기회주의적 행동이 과거의 협동관계가 불량할수록 희석되는 경향이 있음을 발견한 바 있다. 실증연구에서는 기회주의의 역할에 대하여 이와 같이

7) 인적 자산을 조작적으로 정의한 측정변수들의 내적 일관성과 수렴타당성 및 판별타당성이 높은 것 으로 나타난 문헌들의 예는 Rindfleisch 와 Heide(1997) 를 참조. 
상반되는 견해를 보이고 있으나, 대체로 기회주의는 거래 당사자간의 관계나 성과에 부정적 영향을 미치고 있는 것으로 나타나고 있다.

한편 기업이 교환관계에 투자한 특수자산을 보호할 필요가 있을 경우에는 일반적으로 수직적 통합을 통하여 거래비용을 극소화하려 한다고 가정하고 있다. WIII amson(1985)이 제안한 이러한 명제는 부품조달이나 외국시장 진출방식을 포함한 다수의 실증연구에서 지지되고 있다.

요컨대 거래비용이론에서 기회주의에 관한 가정은 실증연구에서 엇갈린 지지를 보이고 있으나 특수자산을 보호하기 위한 수단으로 일반적으로 지배(governance) 및 수직적 통합을 이용하고 있음을 확인할 수 있다. 초기의 실증연구에서는 다수의 기업들이 수직적 통합을 통하여 발생가능한 기회주의적 행동으로부터 자신의 특수자산을 보호하려는 시도를 보여주고 있으나, 기업들은 수직적 통합 외에도 준(準)수직적 통합(quasi-vertical integration), 거래 당사자의 선정, 절차 및 관계규범의 개발과 같은 다양한 형태의 혼합 지배 메카니즘을 추구함으로써 특수자산을 보호할 수 있음을 제시하고 있는 연구도 찾아볼 수 있다( Hei de 1994).

둘째, 기업의 의사결정자가 한정된 합리성으로 인하여 외부환경의 변화에 따른 계약협정을 수정하기가 어려울 때 적응(adaptation) 문제가 발생한다. 따라서 기업과 같은 경제조직을 하나의 복잡한 적응 시스템으로 볼 때 (Foster 2000), 적응문제의 선행조건은 한정된 합리성과 환경적 불확실성이다. 한정된 합리성을 명시적으로 평가하고 있는 문헌은 거의 찾아볼 수 없기 때문에 여기에서는 환경적 불확실성에 대하여 논의의 초점을 두기로 한다.

거래비용이론에 의하면 환경적 불확실성이 높을수록 계약협정에 적응하는 비용은 증가한다. 지금까지의 실증적 문헌을 보면 환경적 불확실성이 거래비용에 미치는 영향을 연구한 것은 단 한 개에 불과하다(Pilling, Crosby, and Jackson 1994). 이들에 의하면 환경적 불확실성은 교환관계를 발전시키는데 소요되는 ' 사전적' ( ex ante)비용에 유의적인 정(正) (+)의 영향을 미치지만 감독활동에 소요되는 '사후적' (ex post)비용에는 영향을 미치지 않는다. Kl ei n과 Roth(1993)는 환경적 불확실성이 적은 기업들이 높은 기업들에 비하여 유통경로 당사자에 대한 만족도가 높다는 사실을 발견함으로써 환경적 불확실성이 거래비용에 미치는 영향을 간접적으로 지지하고 있음을 보여주었다. WIIi amson(1985) 은 기업이 불확실한 환경에 적응할 필요가 있을 때에는 수직적 통합을 통하여 거래비용을 극소화하려 할 것이라고 제안한 바 있다. 그러나 이러한 명제에 대한 실증적 문헌들을 보면 부분적으로만 지시하고 있음을 보여주고 있다. 좀 더 구체적으로 말하면, 일부 연구자들은 환경적 불확실성이 예상되는 영향을 미치고 있음을 발견한 반면에, 연구자에 따라서는 환경적 불확실성이 전혀 영향을 미치지 않는다고 주장하기도 하고, 또 일부 연구자들은 환경적 불확실성의 유형에 따라서는 실제로 수직적 통합의 저해요인으로 작용한다는 사실을 발견한 바 있다.

요컨대 불확실한 환경에 적응하기 위한 수단으로서의 지배의 역할에 대한 실증적 연구결과를 총체적으로 평가한다면, 일관성이 있는 결론을 내릴 수 없다는 것이다. 소수의 연구자들이 환경적 불확실성이 수직적 통합과 정 $(+)$ 의 관계가 있음을 발견한 반면에, 다수의 연구자들은 상황에 따라 환경적 불확실성이 수직적 통합에 전혀 영향을 미치지 않거나 저해요인으로 작용함을 밝히고 있다. 이와 같이 일관성이 결여된 연구결과가 나온 이유는 환경적 불확실성이 다차원적 구성개념이어서 타당한 조작적 정의를 내리기가 어렵기 
때문인 것으로 보이며, 기업들도 환경적 불확실성이 위험을 수반하거나 기술적 진부화와 같은 문제에 직면할 가능성이 있음으로 인하여 계층적 지배구조의 채택을 주저하는 것이 엇갈린 실증조사가 나오는 이유로 추정된다.

마지막으로 기업의 의사결정자가 한정된 합리성으로 인하여 교환 당사자의 계약이행을 산정하기가 어려울 때, 성과를 평가하는 문제가 발생한다. 따라서 성과에 대한 평가 문제의 선행조건은 한정된 합리성과 행동적 불확실성이다. 위에서 언급하였던 바와 같이 한정된 합리성에 관한 실증적 평가는 아직까지 찾아볼 수 없기 때문에 여기에서는 행동적 불확실성에 논의의 초점을 두기로 한다. 성과에 대한 평가문제는 지배구조에 관한 실증조사에서 별로 다루지 않고 있으나 몇 가지 문헌을 보면 행동적 불확실성이 미치는 영향에 관한 가설을 상당히 지지하고 있다.

행동적 불확실성과 거래비용과의 관계를 공식적으로 검증한 연구는 없지만 기업이 수직적 통합을 통하여 교환 당사자들의 성과(또는 업적) 를 평가하는데 소요되는 비용을 극소하하려 한다는 WIII amson(1985) 의 명제를 실증적으로 예시한 대표적인 문헌으로 Anderson(1985), John과 Wei tz(1988), Joshi 와 St ump(1999) 등을 들 수 있다. 행동적 불확실성과 수직적 통합과의 관계 외에도 기업이 혼합형 지배구조를 통하여 행동적 불확실성과 관련하여 성과에 대한 평가에 소요되는 비용을 감소시키려 한다는 실증적 연구가 있다(Hei de와 John 1990) .

요컨대 한정된 합리성이나 행동적 불확실성과 거래비용간의 관계에 대한 가정을 실증적으로 검증하고 있는 연구는 없지만, 기업들이 성과에 대한 평가의 부담을 덜기 위한 수단으로 수직적 통합을 이용하고 있다는 주장은 실증적으로 폭넓게 지지되고 있다.

지금까지의 논의에서 알 수 있었던 바와 같이, 거래비용이론을 주축으로 발전하여 온 신제도학파 기업이론은 실증적 측면에서 아직까지도 많은 문제점을 내포하고 있다. 그 주된 이유는 첫째, 대부분의 실증적 분석이 초기의 이론(Coase 1937, WIIianson 1975, 1985) 에서 제시된 구성개념에 국한하여 이루어졌기 때문이다. 예컨대 다수의 문헌에서 특수자산을 보호하는 것과 같은 특유의 전제조건을 독립변수로 하고 지배 메카니즘을 종속변수로 측정하고 있으나. 그 외에도 서약(pl edge) (Anderson and Weitz 1992), 자격 부여절차( Hei de and John 1990), 감독(St unp and Hei de 1996) 및 계약(Joskow 1987) 등과 같은 다양한 메카니즘이 제시되어, 이와 관련된 실증적 연구가 부족함으로 인하여 이론개발에 제약이 되고 있다. 둘째, 연구자에 따라 핵심적 구성개념에 대한 조작적 정의가 상이함으로 인하여 조사결과들이 통일적 근거를 제시하지 못하고 있다(Ghoshal and Mbran 1996) .

그러나 보다 본질적인 문제는 이론상 불확실성의 개념이 기회주의나 한정된 합리성에 못지 않게 거래비용을 설명하는 핵심적 토대를 제공하고 시장의 조정에서 내부조직(즉, 기업)으로의 전환을 개념적으로 분석하는 연결고리의 역할을 수행하고 있는 중요한 가정임에도 불구하고 이에 대한 연구가 실증적으로나 이론적으로 미흡하여 이를 재평가할 필요가 있고(Slater and Spencer 2000), WIIi amson을 비롯한 다수의 학자들이 거래비용을 조작적으로 정의하기가 어려운데도 불구하고 이에 집착함으로써 방법론상 연역적 추론에 의존하고 있는 주류경제학이 이론발전에 기여할 가능성이 배제되고 있다는 점이다 Pratten 1997). 이와 더불어 거래비용이론이 기업의 성격을 설명하는데 있어 역사적 진화과정을 간과하고 있다는 비판도 제기되고 있다(Pitel is 1998). 


\section{4. 통합적 이론개발의 가능성 모색}

이상과 같은 논의과정을 통하여 알 수 있는 바와 같이 거래비용 중심의 신제도학파 기업이론은 실증적으로나 이론적으로 기업의 성격을 설명하는데 상당한 기여를 하였음에도 불구하고 방법론적 측면이나 개념적 틀에서 보면 다수의 결함이 있음을 노정(露呈)시키고 있다. 따라서 기업의 성격에 관한 거래비용이론을 행동과학을 주축으로 하는 경영이론과 접목시킬 필요가 제기된다.

그러나 신제도학파 옹호론자와 경영학자(특히 경영사학자)간에는 방법론에서 출발점이 극히 상이함으로 인하여 학제간 공조가 거의 이루어지지 못하였다. WIIianson( 1975, 1985) 의 분석은 신고전 경제학과 마찬가지로 비교정태적 접근방법을 이용하여 경제적 환경과 같은 외생적 변수의 변동에 따라 기업과 시장의 경계선이 바뀐다고 설명하고 있다. 이러한 변화가 이루어지는 과정은 중요하지 않다고 가정하며, 따라서 기업과 시장이라는 시스템이 조정되어 균형을 이룰 때, 그러한 균형은 그러한 시스템이 조정되는 또 다른 시스템에 영향을 미치지 않는다. 이와는 달리 기업의 발전에 대한 Chandl er(1977, 1990, 1992) 의 '단계적 접근방법' (stages approach)에서는 기업의 혁신적 성장전략과 그에 따른 전문경영자 중심의 계층구조간의 복잡하고 동태적인 상호작용을 부각시키고 있다. ${ }^{8)}$ 실제로 WIII anson은 몰역사적 방법론과 이념적으로는 그렇지 않다 하더라도 시장에 대한 신고전적 집착을 결합한 결과, Chandl er의 역사적 증거를 오용하였다는 비난을 받아 왔다.

그러나 경영학, 그 중에서도 특히 경영사(史)에서 기업의 조직에만 관심을 두지 않는 것과 마찬가지로 신제도학파의 관심사는 거래비용에 그치지 않는다. 양자가 모두 혁신 및 경쟁우위와 성숙단계의 경제가 쇠퇴하는 원인에 관심을 두고 있다는 것은 경영사의 이론적 기반이 확대되어 온 반면, 신제도학파의 기업이론이 경영사에 의존하는 경향이 증가하고 있음을 의미하고 있다. 이에 따라 근래에 이르러 Cyert와 $\operatorname{March}$ (1963)와 같은 행동과학자, Penrose(1959) 의 ' 기업성장론' 및 Schumpeter(1934)의 기업가 정신에 관한 저작을 토대로 거래비용이론의 단점을 보완하기 위한 시도로 진화론(evol utionary theory)이 대두되었다. 이하에서는 이러한 진화론이 거래비용이론과 경영사적 방법론을 접목시킴으로써 기업의 동태성을 보다 설득력 있게 설명할 수 있음을 보여주기로 한다.

\section{1 기업의 경계선에 대한 새로운 시각}

앞에서 언급하였던 바와 같이, 거래비용이론 가운데 자산 특수성 접근방법이 이론적으로나 실증적으로 한계가 있음에도 불구하고 기업의 경계선이 기본적으로 기술적 분리불가능성에 따라 결정된다는 전통적 견해는 WIII amson에 의하여 전복되었는 바, 그가 거래비용과 지배비용은 물론 생산공정의 실제 특성도 고려하여야 한다고 주장한 것은 올바른 시각이라고 할 수 있다. 그러나 이미 논의하였던 바와 같이 시장과 계층조직간의 선택은 단기에서조차 명백하게 구분되지 않으며, 장기적으로 채택될 혼합형 조직형태는 Wlliamson 모델의 범위를 벗어난 것이 분명하다. 따라서 그의 비교정태적 접근방법은

\footnotetext{
8) 실제로 Chandler(1992)는 거래를 분석단위로 하고 교환과정에 주목하는 Williamson 에 대한 지지를 철회하고 기업이라는 조직과 생산측면에 관심을 두는 진화론을 지지한다고 밝혔다.
} 
필연적으로 전략과 구조의 상호작용이 기업의 미래 경계선에 어떻게 영향을 미치며 경쟁우위를 확보하고 고양시키기 위하여 어떠한 조치가 필요한가에 대한 통찰력을 제공할 능력이 결여되어 있다. 그 이유는 신제도학파의 토대를 제공하고 있는 WIIiamson과 대리(代理) 비용 이론가들의 착상이 대부분 신고전 경제학에 뿌리를 두고 있기 때문이다.

그러나 신제도학파 기업이론은 구(舊)제도경제학과 마찬가지로 통일된 이론과 사상을 지니고 있지 않다. 예컨대 WIIIiamson(1975)이 거래비용 접근방법을 개발하고 있을 때, Ri chardson(1972) 은 기업을 기업이 이용가능한 자원 또는 조직역량( or gani zati onal capabilities)과 연계시킴으로써 기업의 경계선을 탐구하기 시작하였다. 그는 산업활동을 기업들이 상호 밀접한 관련이 있는 밀집된 하나의 협동 네트워크로 보는 것이 보다 현실적이라고 주장하면서, 시장과 계층조직(즉, 기업)을 양분하는 것은 극히 단순한 착상이라고 폄하하였다. 그에 관한 한, 주식의 공유나 장기계약 또는 단순한 신용만으로 유지되는 협동은 시장에서의 비인격적 요소를 제외한 모든 공급업자들과 고객들과의 대규모 네트워크를 확산시키고 지원할 의무와 확신이 내재되어 있는 규범이다. 이것은 기회주의와 부당한 위협이 존재하지 않음을 의미하는 것은 아니며, 경제활동을 사회적 맥락에서 볼 때 사회적 관행과 가치관을 명성을 유지할 필요성과 결합시키면 항구적 연합관계가 형성되어 기회주의나 부당한 위협들이 미치는 영향이 완화될 수 있음을 뜻한다.

Ri chardson에게 있어 기업의 경계선을 결정하는데 보다 중요한 요소는 특정 기업이 이용할 수 있는 자원 또는 조직역량이다. 어느 기업이 조직역량의 성격과 이를 활용하는 정도에 따라 확장범위가 제약되는 조건 하에서 경쟁적으로 활동하려면 여러 가지 역량이 적절하게 결합되어야 한다. 이러한 점에서 그의 기업관은 기업에 내재되어 있는 지식, 숙련도 및 경험은 물론 필요한 원료와 기술적 자원에 대한 통제력 등이 포함된 조직역량을 주창한 Penrose(1959) 의 착상과 유사하다. 즉, 기업은 자신의 역량으로 비교우위가 있는 활동에 전문적으로 종사하며, 타기업과의 판매와 구매활동은 상이한 역량이 결합되어 이루어진다. 기업의 여러 가지 활동은 밀접한 보완적 관계를 지니고 있으나, 조직역량은 상이한 활동을 필요로 한다. 따라서 보완적 활동들은 통합보다는 협동에 의하여 조화를 이루는 것이 바람직하다. 협동은 소유권 면에서 두 개의 기업이 존재하더라도 한 기업이 지배적인 동업자의 위치에 있을 경우에는 거의 이루어지게 마련이다. 다수의 구매자와 판매자가 존재함으로 인하여 수요와 공급이 안정되어 있을 때에는 거래 당사자들은 협동을 회피하고 비인격적 시장의 작동에만 의존하려 한다.

\section{2 조직역량의 중요성}

Ri chardson( 1972) 에 의하면 기술이전에 관한 한, 인가(Iicensing) 를 받은 사람이 인가자(Iicensor)로부터 미래에 특허기술을 사용할 수 있는 보장을 얻으려 할 뿐 아니라 그러한 기술을 효과적으로 사용할 보증을 확보하기 위해서도 특별한 유형의 협동 또는 조정이 필요하다. 따라서 기술이전에는 인가(또는 특허)와 설계도의 소유뿐만 아니라 공장을 가동하는데 기본적으로 필요한 특유한 형태의 지식이라 할 수 있는 기술지원도 필요하다.

특유의 독점적 지식을 이전하는데 따르는 본질적인 어려움을 최초로 제기한 사람은

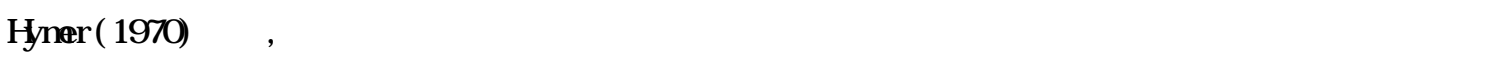
인가(Iicensing) 과정을 통하여 기술적 지식을 효과적으로 이전하는데 따르는 문제들에 
기인한다고 주장하였다. 그 후 Buckl ey와 Casson(1985)과 같은 학자들은 보다 보편적인 내부화 이론을 개발하였는 바, 그 요체는 흔히 기업의 핵심적 역량을 구성하고 있는 특유의 지식(예컨대 숙련도, 지식 및 경험 등)이 정상적인 계약수단으로 성문화하거나 이전 또는 통제하기가 거의 불가능하다는 것이다. 해외에 사업을 확장하고자 하는 기업은 특유의 지식을 이전하는데 거래비용이 많이 소요되기 때문에 자신이 보유하고 있는 고유의 역량에서 발생하는 지대를 극대화할 것을 원할 경우에는 해외에 자회사를 설립하려 할 것이다( Pal enzuel a and Bobill o 1999).

그러므로 거래비용은 어느 기업이 단순상품수출, 인가(Iicensing) 혹은 자회사의 설립 등 어떤 방식으로 해외에 진출할 것인가를 결정하는데 고려하여야 할 중요한 요소이다. 일반적으로 기술수준이 낮거나 서비스업에 속하는 다수의 다국적 기업들도 일상적 과업과 기업문화가 정착된 무형의 역량을 지니고 있어 그것이 지대를 창출하는 중요한 자산의 역할을 수행하고 있음이 분명하지만, 기업 특유의 지식을 이전하는데 따르는 문제들은 첨단기술산업의 경우에 훨씬 심각하고 중대하다(Burgel and Murray 2000). 전자의 경우에 일상적 과업과 기업문화가 정착되면 품질보증을 제공하게 되며, 이것이 브랜드나 기업의 명성과 결부되면 관례가 형성되고 지대를 높이게 된다. 더구나 수준이 낮은 기술은 해외에서 쉽사리 모방될 수 있고 생산공정과 제품은 특허권이나 상표법으로 적절하게 보호받지 못할 수가 있으므로 그러한 기술을 보유하고 있는 기업은 선발주자로서의 우위를 이용하기 위하여 자회사(또는 현지 법인)를 설립함으로써 해외시장을 확보하려는 노력을 기울이게 된다.

물론 노하우를 성문화하고 이를 인가하는데 따르는 여러 가지 난관이 존재한다는 사실이 다국적 기업활동의 유일한 논거를 성립시키는 것은 아니며, 특히 생산단계마다 상이한 활동으로 구성되어 있을 때 그러한 활동들이 보완적 역량보다는 유사한 역량을 필요로 하는 수직적 통합의 경우에 그러하다. Teece(1983)에 의하면 특수거래(transactionspecific)자산 소유자가 Y국에서 유일한 공급자로부터 부당한 위협을 받을 경우에 법적 배상이나 재계약 체결에 한계가 있다고 믿고 있을 때 그러한 자산의 개발이 X국에서 이루어진다면 수직적 통합이 적절할 수가 있다. 그러나 국가마다 조세 및 관세제도, 과실송금에 대한 제한조치, 투자 유치국의 보조금 지원, 기타 합작투자에 대한 장려제도 등과 같은 여타 제도적 특성의 차이를 고려하여 수직적 통합이 발생할 수 있음을 인식하여야 한다. 이러한 제도적 특성은 생산비, 거래비용 및 수송비 등과 함께 내부화가 적절한 전략인가의 여부를 결정할 때 고려하여야 할 변수들이다.

\section{3 경쟁우위의 확보를 위한 조직역량의 배양}

국제교역에 대한 내부화 접근방법은 이와 같이 조직역량, 거래비용 및 기타 제도적 특성을 절충하여 결합함으로써 수직적 및 수평적 통합을 분석하는데 WIIi amson이 제안한 것 보다 휠씬 포괄적인 틀을 제시하고 있다. 그러나 내부화 이론은 전략적 의사결정을 내릴 경우에 미래에 발생할 사태를 고려할 수 있겠지만, 시간이 경과함에 따라 기업의 역량이 변동될 방식이나 그러한 변동이 경영층이 당면하고 있는 의사결정에 어떻게 영향을 미칠 것인가에 관하여는 이야기하고 있는 바가 거의 없다.

기업의 공개적 활동은 특정된 시점에서 기업이 이용할 수 있는 일단의 자원 또는 역량에 따라 필연적으로 제약된다. 앞에서 언급하였던 바와 같이 기업의 역량은 어디서나 쉽사리 
모사할 수도 있는 유형자산과 일상적 과업이나 기업문화 및 종업원들의 집단적 기억력 등이 내재화된 숙련도와 지식의 형태로 표출되는 특유의 무형자산으로 구성되어 있다. 이러한 여러 가지 역량은 각기 분리되어 발휘될 때 보다는 결집되어 산출물을 더 적은 비용으로 생산할 수 있을 때 시너지 효과를 거둘 수 있으며, 기업은 이러한 경우에 비교우위를 누릴 수 있다. 그러나 Ri chardson(1972)이 언급하였던 바와 같이 어떠한 기업도 고립된 섬이 아니며 기업을 효과적으로 운영하려면 각기 특유의 결집된 역량을 보유하고 있는 여타 기업들이 제공하는 보완적 자산에 쉽사리 접근할 수 있어야 한다. 경우에 따라 전시에 부대를 대폭적으로 재배치하는 것과 같이 다수의 기업들이 실제로 산출물을 광범위하게 생산할 수 있다 하더라고 특정 기업의 활동이나 산출물은 보유하고 있는 자원의 기반에 따라 제약된다(Teece 1996). 산출물에 대한 합리적 의사결정은 결집된 역량을 수요조건에 맞추는 것을 근거로 삼아야 하겠지만, 기업이 실제로 생산하는 것은 소유주와 경영층의 재량에 좌우되기 쉽다.

그러나 기업의 역량은 어떠한 기간을 통하여도 안정되어 있을 경우가 드물다. 그 이유는 시간이 경과함에 따라 조직구성원들이 이미 알려져 있는 일상적 과업에 의하여 대치되는 어떤 기능을 수행하는데 시행착오 과정을 통하여 자신들의 과업을 보다 효율적으로 수행할 방법을 터득하기 때문이며, 그러한 일상적 과업은 필요에 따라 차후에 정교화 되고 적응된다. Penrose(1959)가 강조하였던 바와 같이 조직의 학습결과는 일정한 산출물을 생산하는데 인적 및 기타 자원이 보다 적게 소요됨으로써 기업의 전반적 역량을 증대시키는 효과로 나타난다. 기업이 잉여자원을 기존의 사업부문에 재투자할 것인가 또는 다양화할 것인가, 혹은 잉여자산의 서비스를 다른 기업에 매각할 것인가의 여부는 기존시장에서의 수요상태, 기업의 역량을 새로운 산업에 배치하여 수익을 거둘 수 있는가의 여부 및 극히 특유한 무형자원에 대하여 계약을 효과적으로나 경제적으로 체결할 수 있는 능력 등에 달려 있다. 따라서 일상적 과업들을 분리할 수 있을 경우에는 개인이나 팀을 통하여 무형의 자원을 이전할 수 있겠지만, ' 조직의 경계선을 넘어선 외부이전은 불가능하지는 않다 하더라도 어려울 수가 있는 바, 그 이유는 그러한 상황을 배제하고 해석하면 하나의 일상적 과업에 대한 개인의 지식은 무용지물이 될 수 있기 때문이다' (Teece 1996, p.178). 한 기업의 소유자가 거래비용이 많이 소요되는 상황에 직면했을 때에는 기업의 경계선을 연장하여 잉여자원을 이용하거나 자신에 대한 보상 여부와 관계없이 그러한 자원을 포기하여야 할 것인가를 고려하여야 한다.

경쟁우위를 유지하기 위한 전략의 일부로 핵심적 조직역량이 추가로 개발됨에 따라 기업의 경계선도 변동될 수 있다. 핵심적 역량을 추가하는 것이 기업의 생존에 필요불가결한 이유는 Langl oi s와 Robertson(1995)이 지적하였던 바와 같이 개별 기업들이 시간의 경과에 따라 역량이 점진적으로 증가할 수 있는 반면, 여타 기업들도 선도기업이 개척하여 일상적 과업으로 전환된 기법을 터득하고 모방기업들이 적응함에 따라 역량이 증대되기 때문이다. 따라서 단기간에 경쟁이 불가능한 특유의 핵심활동들은 장기적으로는 역량이 시장에 완전히 보급되어 전문화와 수직적 분해가 전면적으로 발생되면서 완전한 경쟁대상이 된다. 바꾸어 말하면, 거래비용은 처음에는 기업의 경계선을 결정하는데 도움이 되지만 그때까지 기업 특유의 우위를 부여하였던 제(諸) 역량이 전체산업에 널리 보급되고 일상화됨에 따라 점차 감소된다.

Barney(1999) 도 조직역량이 기업의 경계선에 대한 의사결정에 영향을 미친다는 견해에 동조하고 있다. 그는 급격히 발전하는 첨단기술산업에서는 비계층적 지배구조를 통하여 
역량에 접근하는 것이 기회주의의 위협을 유발할 가능성이 있음에도 이를 선호하리라고 본다. 그러한 기업들이 자체 역량을 개발하거나 그러한 역량을 이미 보유하고 있는 다른 기업을 인수하려면 상당한 비용이 소요되기 때문에 시장이나 중간의 지배구조 형태를 이용하는 것이 보다 매력적인 대안이 된다. 역량을 입수하기 위하여 계층적 지배를 이용하는데 소요되는 비용은 역량에 접근하기 위하여 비계층적 지배를 이용하는데 소요되는 비용과 비교하여야 한다. 특수거래투자(transaction- specific investment)에서 발생하는 기회주의의 위협은 이러한 경계선에 대한 의사결정을 내리는데 고려하여야 할 중요한 요소 중의 하나이지만 유일한 고려요소는 아니다. 달리 말하면 한 기업이 접근하고자 하는 역량의 속성은 해당 기업의 경계선을 결정하는데 중대한 영향을 미칠 수 있다.

그러므로 기업이 경쟁우위를 확보하고 지대를 계속 추출하여 성공을 거두려면 새로운 전략을 개발하고 새로운 역량을 배양하지 않으면 안 된다. 새로운 전략의 선택은 과거의 전략을 수용하기 위하여 개발된 조직구조와 일상적 과업과 함께 기업이 보유하고 있는 본래의 자원기반에 따라 제약되는 것이 거의 불가피하다. 따라서 전략이 통상적으로 발전하는 방식에는 경로의존(path dependency)의 요소가 존재한다. 그러나 성공한 기업은 현재의 역량을 활용하기 위하여 학습곡선을 따라 신속하게 이동하고 새로운 기회가 발생할 때마다 이를 이용할 가능성에 계속 주의를 기울이기 위한 확실한 보장책으로 일상적 과업이 정착되면서 지속적으로 학습하는 기업이다. 첨단기술산업에서는 그러한 활동이 대부분 연구개발부에서 이루어질 가능성이 많으나, 그러한 기회를 이용하려면 기업의 구조와 문화가 모두 학습과 변화를 지지할 수 있는 것이어야 한다.

그러나 기술적 혁신이나 조직혁신의 성과를 모두 전유하려면 기업 특유의 새로운 우위를 창출할 필요가 있으며, 이를 위하여 기업 내의 역량을 개발함은 물론 이와 병행하여 원료 및 부품 공급자와 유통업자들의 역량도 개발할 필요가 있다. 그와 같은 체계적 변화는 하나의 네트워크가 제대로 작동되어 밀접한 협동 하에 비교적 비용을 들이지 않고 달성될 수 있지만, 기존의 네트워크 내부나 외부에 있는 기업이 필요불가결한 부수적 자산을 개발할 의사나 능력이 없을 가능성이 존재한다. 그 이유 중의 하나는 변화의 성격이 고도로 특유하거나 혁신이 극히 참신함으로 인하여 혁신자가 새로운 필요조건들을 잠재적 공급자나 유통업자에게 포괄적으로 전달하기가 쉽지 않기 때문이다. 이와 같이 거래상의 장애가 주어졌을 때, 혁신자는 기업의 경계선을 확장하여 필요한 활동 자체를 수행할 책임을 맡지 않을 수 없을 경우가 있다. 더구나 혁신자는 새로 창출될 지대가 모방자들이나 부당한 위협에 의하여 착복되지 않도록 보완적이고 공동으로 전문화할 수 있는 자산을 확보할 위치를 차지하려 할 수 있다. 이러한 부수적 역량을 획득하는데 소요되는 비용은 ' 외부 공급자들을 설득하고 이들과 협상하고 조정하며 이들을 훈련시키는데 소요되는 비용' 과 함께 '동태적 거래비용' (dynam c transacti on costs)이라고 불리워 왔다( Langl oi s and Robertson 1995, p. 35). 한 기업이 이러한 동태적 거래비용을 절약할 수 있는 역량을 보유하면 경쟁우위를 차지하고 성장할 수 있으며 수익률을 제고할 수 있음이 분명하다.

\section{4 거래비용 절약수단으로서의 네트워크}

앞에서 언급하였던 바와 같이, 거래비용이론의 일부 단점을 보완하기 위하여 대두된 진화론에서는 조직역량의 개발을 강조함으로써 경영학자(특히 경영사학자) 들에게는 극히 유용한 이론적 틀이 될 수 있음을 시사하고 있다( Nel son and Wnter 1982). 진화론은 
혁신의 경로의존을 부각시킴으로써 기업 특유의 일상적 과업이 기술의 선택에 미치는 영향을 보여줌으로써 기업의 발전이 수렴되기 보다는 분기된다는 것을 설명하는 귀중한 토대를 제공하고 있다. Langl oi s와 Robertson(1995)은 거래비용이론과 역사적 방법론을 결합하여 ' 동태적 기업제도론' (dynamic theory of busi ness institution)을 제안함으로써 진화론의 유용성을 입증하고 있다. 그들은 19세기 말 이후에 기업이 대규모화되고 중앙집권적 관리체제가 형성된 것은 혁신과 성장을 위한 하나의 방편임을 논증한 바 있다. 그들의 주장에 의하면 중소기업들이 느슨한 네트워크나 전략적 제휴, 또는 합작의 형식을 선호하여 경쟁우위의 토대가 형성될 것인가의 여부는 문제의 성격, 제품수명주기상의 단계 및 정보의 이용가능성에 달려 있다.

경우에 따라 네트워크는 통합에 대한 경쟁적 대안임을 나타낸다는 착상은 경영사적 입장에서 매우 중요한 단서를 제공함으로써 WIIi amson과 Chandl er 의 접근방법으로부터 이탈되는 시발점이 되었다. 예컨대 WIII anson(1991)은 시장과 기업의 양극단보다는 양자의 중간형태인 혼합형 지배구조가 보다 안정적이지만 예외적인 것으로 보고 있다. Chandl er(1990) 도 이와 유사한 맥락에서 기업들의 연대(또는 제휴)가 존재하지만 일시적이라고 믿었던 반면, Kogut (1989)는 합작투자가 극히 불안정함을 보여주었다. 이러한 연구결과들은 기업의 그룹화(groupi ng)가 보다 효율적으로 통합된 기업으로 전환되는 과정의 한 단계임을 시사하고 있다. 이것은 경제발전론에 관한 문헌에서 기업의 그룹화가 초기의 경제발전단계에서 발생하는 시장실패의 신호라는 다수의 공통적 견해와 일치하고 있다.

네트워크가 중간형태의 조직에 불과하다는 WIII amson과 Chandl er 의 견해는 서구에서 경제력 집중을 초래하였다는 비판을 받고 있다. 그러나 동아시아에서 가족기업과 그 네트워크를 분리한다는 것은 불가능하다. 한국을 포함하여 대만이나 홍콩과 같은 사회에서는 네트워크가 고도로 정착되어 있어 시장과 기업간의 중간단계라기보다는 고유의 경제제도로 간주할 수 있다. ${ }^{9}$ 다른 한편, 국제적으로 비교한 연구결과를 보면 20세기에 걸쳐 느슨한 네트워크가 계속 존재하여 동아시아는 물론 서구에서도 국제적 경쟁우위의 중요한 토대를 형성하고 있다는 증거가 점차 제시되고 있다. 예컨대 미국의 대기업에서는 계열기업간의 임원겸직제도를 택함으로써 사회적 유대를 수직적으로 창출하고 있으며, 특히 대기업과 금융기관간에 그러하다. 이와는 달리 이태리에서는 중소기업형 직물 및 의류산업이 보다 공식적인 집단을 이루어 국제적 경쟁우위의 토대를 형성하고 있음은 잘 알려져 있다.

WIII amson(1994)이 네트워크를 단순히 중간형태의 조직으로 본 이유 중의 하나는 그가 기업을 비롯한 모든 제도가 계약을 토대로 하고 있다는데 관심을 집중함으로써 권력과 권한 및 문화적 요인들이 경제조직에서 중요한 변수들이라는 착상을 거부하였기 때문이다. 그러나 신제도학파 이론가들의 일부는 족벌기업이나 이와 유사한 기업들을 토대로 이론을 발전시켰는 바, 이것은 기업 내는 물론 기업간의 네트워크의 연구에 이론적 토대를 제공하고 있다. 예컨대 Ben- Porath(1980) 와 Pol I ak(1985) 및 Al vesson과 Li ndkvi st (1993) 등은 거래비용이론을 가족의 행동에 적용하여 기업 내에서 족벌을 통한 비공식적 통제가 공식적인 관료적 조직보다 효율적인 환경요인들을 부차적으로 분석하고 있다.

\footnotetext{
9) 경제력 집중으로 독점화가 심화되어 시장과 기업의 경계선이 명확히 구분되는 서구경제와는 달리 가족기업의 형태로 네트워크를 중시한 동아시아(특히 대만이나 홍콩)에서의 예를 제시한 문헌으로는 Redding(1990), Hamilton and Feenstra(1995), Biggart and Hamilton(1992) 등을 들 수 있다.
} 
거래비용이론에서는 위험한 환경 하에서 거래가 정규적으로 이루어질 때에는 관료적 제도가 불확실성을 감소시켜 효율을 증대시킬 것이라고 묵시적으로 가정하고 있다. 그러나 어떤 환경요인들은 위험도가 매우 높아 시장이나 기업에 의하여 통제될 수 없다는 문제가 제기되어 왔다. 그 결과, 기업 내에서 공식적인 규정과 규제장치 보다는 유사한 배경을 공유하거나 기업문화를 창출함으로써 조직구성원들의 태도, 열망 및 목표의 공유를 토대로 통제가 이루어질 때 거래비용은 감소할 것이다. 그러므로 족벌기업과 같은 조직에서는 공식화되고 정교화된 정보입수 방식보다는 조직구성원들의 공통적 아이디어, 신념 및 가치관 등이 그러한 기능을 대신함으로써 행동지침의 구심역할을 수행한다.

그러므로 네트워크의 개발과 성과를 명백하게 이해하려면 권력과 신뢰관계가 형성되는 방식과 그것이 기업행동에 미치는 영향을 알 필요가 있다. Beccerra와 Gupta( 1999)는 신뢰가 포함된 거래비용이론이 신뢰를 배제한 이론에 비하여 조직간의 관계를 보다 심도있게 설명할 수 있음을 실증적으로 예시하고 있다. Casson(1993) 도 거래비용과 신뢰의 개념을 연계시킴으로써 기업가의 행동과 기업 내 와 기업간의 네트워크 형성에 관한 시사점을 얻을 수 있다고 주장하였다. 이러한 접근방법은 특히 친족은 물론 가까운 동료와 동업자 등이 포함된 족벌기업의 경계선을 연구하는데 적절하다. 가족을 비롯한 조직구성원들은 숙련기술, 노동력 및 자금의 출처라는 단순한 차원을 넘어 신뢰로 하나의 네트워크를 형성하며, 이를 통하여 거래비용과 사업활동의 위험 및 불확실성이 감소될 것이다. 따라서 족벌은 경영계층의 내부시장, 창업 및 사업확장을 위한 자금출처 및 시장정보의 출처로 볼 수 있지만, 족벌기업의 경계선은 보통 동질적 문화와 가치관을 공유하고 있는 다소 광범위한 집단 내에 위치하고 있다.

만일 신뢰가 곧 거래비용의 감소를 의미한다면, 정보비용은 정보출처의 신뢰성과는 무관하게 발생한다. Casson(1998) 은 경제활동의 가장 중요한 요소가 정보의 흐름이라고 보고, 이에 초점을 두어 시간의 경과에 따라 변화하고 있는 환경에 조응하여 '시장을 조성하는' 방법들이 기술적, 기업가적 및 문화적 요인의 결합으로 어떻게 선택되고 발전하는가를 탐구하고 있다. 그는 제품조직보다 정보조직에 관심을 기울여 기업과 여타 유형의 경제조직간의 상호작용을 강조한다. 그가 제안한 분석기법의 특징은 거래비용이론의 요소와 진화론 및 기업가 정신이론을 결합하고 있다는 것이다. 그는 이러한 기법을 이용하여 신제도학파 기업이론이 한걸음 더 발전할 ' 중도노선' 의 입장을 취하고 있다.

\section{5 마케팅상의 함의(含意)}

지금까지 논의한 바와 같이 거래비용이론과 진화론을 결합한 통합적 접근방법은 마케팅 측면에서도 중요한 의미를 내포하고 있다.

첫째, 마케팅 연구자들은 전통적으로 거래비용이론 가운데 수직적 통합, 특히 자산 특수성 접근방법에 실증적 분석의 초점을 둠으로써 전략과 구조의 상호작용이 기업의 경계선에 미치는 영향과 경쟁우위를 확보하기 위하여 필요한 조치를 구체적으로 제시하지 못하였으나, 본고에서 제안한 통합적 접근방법을 실증적으로 연구하게 되면 기업이 자신의 역량으로 경쟁우위가 있는 활동에 종사하고 타기업과의 판매와 구매활동도 상이한 역량이 결집되어 이루어지고 있음을 보일 수 있을 것이다.

둘째, 거래비용은 국제시장 진출방식을 결정하는데 고려하여야 할 중요한 요소이지만 기업의 조직역량의 배양으로 형성된 명성(브랜드가 대표적임)도 경쟁우위의 기초가 된다. 
따라서 조직역량, 거래비용 및 기타 제도적 특성(예컨대 무역제도)을 절충한 통합적 접근방법에 대한 실증분석은 보다 설득력 있는 틀을 제시할 것이다.

셋째, 본고에서 제안한 통합이론을 실증적으로 연구하게 되면 기업 내의 역량은 물론 원료 및 부품공급자와 유통부문 종사자들의 역량도 개발할 필요가 있음을 제시할 수 있을 것이다. 이러한 체계적 변화는 하나의 네트워크가 제대로 작동되어 밀접한 협동 하에 달성될 수 있고, 경우에 따라 네트워크가 거래비용이론에서 초점을 두었던 통합(수직적 및 수평적 통합) 에 대한 경쟁적 대안임을 입증할 수 있을 것이다.

\section{5. 요약 및 결론}

본고의 서두에서 언급하였던 바와 같이 신제도학파 기업이론은 신고전학파의 맹점을 극복하여 조직문제를 포괄적으로 다룰 수 있음을 보여줌으로써 마케팅을 비롯한 경영학과 경제학은 물론 사회과학 전반에 걸쳐 새로운 패러다임으로 각광을 받고 있다. WIIi amson은 거래비용, 한정된 합리성, 기회주의 및 자산 특수성과 같은 개념들을 산업조직이론의 중심적 위치로 이동시킴으로써 기업의 경제적 행동을 분석하고 이해하는데 크게 기여하였음이 입증되고 있다. 이것은 특히 마케팅을 중심으로 여타 사회과학에 진행되어 온 다수의 실증적 연구결과물에서 명백하게 제시되고 있으며, 본문에서 핵심적 개념들을 측정한 문헌들을 열거한데서 이를 엿볼 수 있다.

그러나 그가 제시한 이론적 틀은 두 가지 면에서 주요 결점을 안고 있다. 그 하나는 이론의 정당성을 입증하기 위하여 주요 구성개념을 측정가능한 변수로 전환하여 실증적으로 분석한 무수한 연구문헌들이 나와 있으나 연구의 타당성이 결여되어 있다는 점이다. 그 원인 중의 하나는 측정이 원천적으로 불가능한 구성개념도 존재하기 때문이다. 한정된 합리성과 같은 개념이 대표적인 예에 속한다. 또 하나의 결정적 결함은 그가 택한 신고전학파의 비교 정태적 접근방법이 몰역사적이고 범위가 극히 한정되어 있어 기업행동의 일부만을 설명하는데 그치고 있다는 것이다. 주어진 환경 하에서 거래비용을 절약하는데 초점을 두고 있는 선택의 이론적 틀은 새로운 선택장치가 발전되는 성장과정과 방식을 도외시하고 있다. Lazonick(1993)이 지적하였던 바와 같이 초기의 신제도주의자들은 전략개발과 구조적 변동을 이해하는데 필수적인 조직과 기술간의 동태적 상호작용의 중요성을 깨닫지 못한 것으로 보인다.

이에 따라 본고에서는 국제교역 이론가들이 제시한 기업 특유의 경쟁우위에 관한 착상과 기업 특유의 우위가 기업의 결집된 역량에서 도출된다는 견해를 거래비용이론에 접목시킴으로써 기업의 성격과 그 성장방식을 보다 설득력 있게 이해할 수 있으리라는 관점을 제시하려 하였다. ${ }^{10)}$ 또한 기업 내외의 네트워크 형성이 신뢰를 낳고 이를 통하여 거래비용이 감소되어 경쟁우위를 차지할 토대가 제공된다는 점을 제시함으로써 거래비용이론과 진화론의 결합 가능성을 제안하였다. 이러한 과정들을 이해하려면 거래비용을 올바르게 평가하는 것이 필수적이며, 거래비용이 기업의 경계선과 시간의

10) 신제도학파의 두 가지 주요 분파가 지니고 있는 신고전적 특성(이는 오스트리아 학파의 입장임)에 관해서는 Rutherford(1996) 가 제시하고 있다. 
경과에 따라 기업 특유의 경쟁우위 보존 여부를 결정하는데 핵심적 요소라는 사실에는 의문의 여지가 없을 것이다.

마지막으로 마케팅 분야(특히 유통분야)에서는 거래비용이론에 관한 실증적 연구가 사회과학분야 중에서 가장 활발하게 진행되어 왔음에도 불구하고 신제도학파 초기의 이론에서 제시된 구성개념에 국한하였기 때문에 이론개발에 크게 기여하지 못하였음을 감안할 때, 본고에서 제시된 통합이론의 틀 내에서의 실증연구는 이론적으로나 실무면에서 마케팅 전략개발에 관한 새로운 관점을 제시해 줄 것으로 생각된다. 예컨대 본연구는 기업이 특유의 경쟁우위를 확보하려면 기업 내의 역량은 물론 원료 및 부품공급자와 유통종사자들의 역량도 개발할 필요가 있음은 물론 네트워크의 형성이 통합에 대한 경쟁적 대안임을 암시하고 있다. 따라서 이에 관한 마케팅에서의 새로운 실증연구는 통합이론의 발전에 기여할 가능성이 높다고 할 수 있다. 
김석용(1996), “신제도학파적 기업이론과 네트워크 이론의 고찰, ” 경영학연구, 제25권

1호( 2월), 107- 151.

여운승(1998), 기업이론, 도서출판 석정.

(1999), “역사적 관점에서 본 기업이론의 전개과정,” 경영학연구, 제28권

2호( 5월), 53964.

Alchain, A. A. and H. Demsetz (1972), "Production, Information Costs, and Economic Organization," American Economic Review, Vol. 62, 777-95.

Alvesson, M. and L. Lindkvist (1993), "Transaction Costs, Clans and Corporate Culture," Journal of Management Studies, Vol. 30, 427-52.

Anderson, E. (1988), “Transaction Costs as Determinants of Opportunism in Integrated and Independent Sales Forces,” Journal of Economic Behavior and Organization, Vol. 9(May), 247-64. , (1996), “Transaction Cost Analysis and Marketing," in John Groenewegen(ed.),

Transaction Cost Economics and Beyond. Boston: Kluwer Academic Publishers, 65-83.

Anderson, E. and Barton A. Weitz (1992), "The Use of Pledges to Build and Sustain Commitment in Distribution Channels," Journal of Marketing Research, Vol. 29(February), 18-34.

Anderson, E. and Anne T. Coughlan (1987), "International Market Entry and Expansion via Independent or Integrated Channels of Distribution," Journal of Marketing, Vol. 51(January), 71-82.

Barney, J. B. (1999), 'How a Firm's Capabilities Affect Boundary Decisions,' Sloan Management Review(Spring), 137-45.

Baumol, W. J. (1959), Business Behavior, Value and Growth, New York: Macmillan.

Beccerra, M. and A. K. Gupta (1999), "Trust Within the Organization : Integrating the Trust Literature with Agency Theory and Transaction Costs Economics," PAQ(Summer), 177-203.

Ben-Porath, Y. (1980), "The FConnection : Families, Friends and Firms and the Organization of Exchange," Population and Development Review, Vol 6, 1-30.

Bensaou, M. B and Erin Anderson (1997), "Buyer-Supplier Relations in Industrial Markets : When Do

Buyers Enter the Trap of Making Idiosyncratic Investments?" working paper, INSEAD, Fontainebleau, France.

Biggart, N. W. and G. G. Hamilton (1992), "On the Limits of Firm-Based Theory to Explain Business Networks : The Western Bias of Neoclassical Economics," in N. Nohria and R. G. Eccles(eds.), Networks and Organizations : Structure, Form and Action, Boston, MA.

Buckly, P. J. and M. C. Casson (1985), The Economic Theory of the Multinational Enterprise.

Burgel, O. and Gorton C. Murray (2000), "The International Market Entry Choices of Start-Up Companies in High-Technology Industries," Journal of International Marketing, Vol. 8(2), 33-62.

Casson, M. (1990), Enterprise and Competitiveness, Oxford : Oxford University Press.

(1993), "Entrepreneurship and Business Culture," in J. Brown and M. B. Rose(eds.),

Entrepreneurship, Networks and Modern Business, Manchester, U. K. 30-54. (1998), "Institutional Economics and Business History : A Way Forward?," in M. Casson

and M. B. Rose(eds.), Institutions and the Evolution of Modern Business, Portland, OR : Frank Cass. Chandler, A. D. (1962), Strategy and Structure, Cambridge, MA.

(1977), The Visible Hand: The Managerial Revolution in American Business, Harvard

University Press : Cambridge, Mass.

(1990), Scale and Scope : The Dynamics of Industrial Capitalism, Belknap/ Harvard

University Press : Cambridge, Mass. 
Economy, Vol. 1(3), 249-69.

(1993), "Transaction Costs and the Evolution of the Firm," in C. Pitelis(ed.), Transaction Costs, Markets and Hierarchies.

Hymer, S. (1970), "The Efficiency Contradictions of Multinational Corporations," American Economic Review, Vol. 60, 441-8.

John, G (1984), "An Empirical Examination of Some Antecedents of Opportunism in a Marketing Channel," Journal of Marketing Research, Vol. 21(August), 278-89.

John, G and Barton A. Weitz (1988), "Forward Integration into Distribution : An Empirical Test of Transaction Cost Analysis," Journal of Law, Economics and Organization, Vol. 4(Fall), 121-39.

Jones, S. R. H. (1982), “The Organization of Work : A Historical Dimension,” Journal of Economic Behavior and Organization, Vol. 3, 117-38.

Joshi, A. W. and Rodney L. Stump (1999), “The Contingent Effect of Specific Asset Investments on Joint Action in Manufacturer-Supplier Relationships : An Empirical Test of the Moderation Role of Reciprocal Asset Investments Uncertainty, and Trust," Journal of the Academy of Marketing Science, Vol. 27(3), 291-305. 
Joskow, P. L. (1987), “Contract Duration and Relationship-Specific Investments : Empirical Evidence from Coal Markets,” American Economic Review, Vol. 77(March), 168-85.

(1988), “Asset Specificity and the Structure of Vertical Relationships : Empirical Evidence," Journal of Law, Economics and Organization, Vol. 4(Spring), 95-117.

Klein, S. and Victor J. Roth (1993), "Satisfaction With International Marketing Channels," Journal the Academy of Marketing Science, Vol. 21(Winter), 39-44.

Kogut, B. (1989), “The Stability of Joint Ventures : Reciprocity and Competitive Rivalry," Journal of Industrial Economics, Vol. X X X III , 183-98.

Kraft, M. (1999), "An Empirical Investigation of the Antecedents of Sales Force Control Systems," Journal of Marketing, Vol. 63(July), 120-34.

Langlois, R. N. and P. L. Robertson (1995), Firms, Markets and Economic Change, London.

Lazonick, W. (1993), Business Organization and Myth of the Market Economy, Cambridge, U. K : Cambridge University Press, 196-7.

Lothia, R., Charles M. Brooks, and Robert E. Krapel (1994), “What Constitutes a Transaction Specific Asset? An Examination of the Dimensions and Types," Journal of Business Research, 30(July), 26170.

Manne, H. (1965), "Mergers and the Market for Corporate Control," Journal of Political Economy, Vol. $73,112-13$.

March, J. G. and H. A. Simon (1958), Organizations, New York : John Wiley \& Sons.

Marris, R. (1964), The Economic Theory of Managerial Capitalism, London : Macmillan.

Monteverde, K and David J. Teece (1982a), "Supplier-Switching Costs and Vertical Integration in the Automobile Industry,” Bell Journal of Economics, Vol. 13(Spring), 206-13. and (1982b), “Appropriate Rents and Quasi Vertical Integration," Journal of Law and Economics, Vol. 25(October), 321-28.

Moschandreas, M. (1997), "The Role of Opportunism in Transaction Cost Economics," Journal of Economic Issues, Vol. 31(March), 39-57.

Nelson, R. R. and S. G. Winter (1982), An Evolutionary Theory of Economic Change, Cambridge, MA.

Osborn, R. N and C. Christopher Baughn (1990), "Forms of Interorganizational Governance for Multiantional Alliance,” Academy of Management Journal, Vol. 33(3), 503-19.

Palenzuela, V. A. and Alfred M. Bobillo (1999), "Transaction Costs and Bargaining Power : Entry Mode Choice In Foreign Markets," Multinational Business Review(Spring), 62-75.

Parkhe, A. (1993), "Strategic Alliance Structuring : A Game Theoretic and Transaction Cost Examination of Interfirm Copperation,” Academy of Management Journal, Vol. 36(August), 794-829.

Penrose, E. T. (1959), The Theory of the Growth of the Firm, London : Basil Blackwell.

Pessali, H. F. and Romon G. Fernandez (1999), 'Institutional Economics at the Micro Level? What Transaction Costs Theory Could Learn from Original Institutionalism (In the Spirit of Building Bridge)," Journal Economic Issues, Vol. 33 (No. 2), 265-75.

Pilling, Bruce K., Lawrence A. Crosby, and Donald W. Jackon. Jr. (1994), “Relational Bonds in Industrial Exchange : An Experimental Test of the Transaction Cost Economic Framework," Journal Business Research, Vol. 30(July), 237-51.

Pitelis, C. N. (1998), “Transaction Costs and the Historical Evolution of the Capitalist Firm," Journal of Economic Issues, Vol. 32(December), 999-1017.

Pollak, P. A. (1985), "Transaction Cost Approach to Families and Households," Journal of Economic Literature, Vol. X X III, 581-608.

Pratten, S. (1997), "The Nature of Transaction Cost Economics," Journal of Economic Issues, Vol. 31(September), 781-803. 
Redding, S. G. (1990), The Spirit of Chinese Capitalism, Berlin.

Richardson, J. B. (1972), “The Organization of Industry,” Economic Journal, Vol. 82, 883-96.

Rutherford, M. (1996), Institutions in Economics, Cambridge, U. K : Cambridge University Press, p.3.

Schumpeter, J. A. (1934), The Theory of Economic Development, Cambridge, MA : Harvard University Press.

Seckler, D. (1975), Thorstein Veblen and the Institutionalists (London), 128-9.

Shelanski, H. and Peter G. Klein (1995), "Empirical Research in Transaction Cost Economics : A Review and Assessment,” Journal of Law, Economics, and Organization, Vol. 11(2), 335-61.

Slater, G. and David A. Spencer (2000), "The Uncertain Foundations of Transaction Costs Economics," Journal of Economics Issues, Vol. 34(March), 61-87.

Stump, R. L and Jan B. Heide(1996), "Controlling Supplier Opportunims in Industrial Relationships," Journal of Marketing Research, Vol. 33(November), 431-41.

Teece, D. J. (1983), "Technological and Organizational Factors in the Theory of the Multinational Enterprise," in M. Casson(ed), The Growth of International Business, London.

(1996), "Towards an Economic Theory of the Multiproduct Firm," Journal of Economic Behavior and Organization, Vol. 3(1982), reprinted in L. Putterman and R. S. Krosner(eds), The Economic Nature of the Firm, Cambridge.

Tsang, E. W. K. (2000), "Transaction Cost and Resource-based Explanations of Joint Ventures : A Comparison and Synthesis," Organization Studies, Vol. 21(1), 215-42.

White, S. (2000), "Competition, Capabilities, and The Make, Buy or Ally Decisions of Chinese Stateowned Firms," Academy of Management Journal, Vol. 43(3), 324-41.

Williams, S. (2000), “An Empirical Application of Transaction Costs Theory to Organizational Design Characteristics," Journal of Psychology, Vol. 134(1), 81-92.

Williamson, O. E. (1975), Markets and Hiearchies : Analysis and Antitrust Implications, New York ; The Free Press. Vol. 1, 5-38.

(1980), “The Organization of Work," Journal of Economic Behavior and Organization,

(1981), “The Modern Corporation : Origins, Evolution, Attributes,” Journal of Economic Literature, Vol. 19(4), 1537-68.

(1985), The Economic Institutions of Capitalism : Firms, Markets, Relational Contracting, New York : The Free Press.

(1988), “Technology and Transaction Cost Economics," Journal of Economic Behavior and Organization, Vol. 10, 358-9.

(1991), "Comparative Ownership and Control : The Analysis of Discrete Structural Alternatives," Administractive Science Quarterly, Vol. 36, 269-96.

(1993), "Transaction Costs Economics and Organization Theory," Industrial and Corporate Change, Vol. 2(2), 107-56.

(1994), "Hierarchies, Markets and Power in the Economy : An Economic Perspective," Industrial and Corporate Change, Vol. 4, 21-49.

(1996), "Efficiency, Power, Authority and Economic Organization," in J.

Groenewegen(ed), Transaction Cost Economics and Beyond, Dordrecht : Kluwer.

(1998), "The Institutions of Governance," American Economic Review, Papers and

Proceedings, 88, no. 2 (May). 